\title{
11. SEDIMENTARY PROCESSES IN THE NORTH ATLANTIC
}

\author{
T.A. Davies, Scripps Institution of Oceanography, La Jolla, California, \\ and \\ A.S. Laughton, National Institute of Oceanography, United Kingdom
}

\section{INTRODUCTION}

The sediments of the North Atlantic north of $45^{\circ} \mathrm{N}$ do not seem to have attracted widespread attention prior to 1940, when Bramlette and Bradley published the results of their studies of cores obtained between Ireland and Newfoundland by the cable ship Lord Kelvin (Bramlette and Bradley, 1940). Since that time, however, a wealth of information concerning the sediments of this region has been gathered through the activities of ships sent out by institutions on both sides of the Atlantic. In a preliminary report, such as the present volume, it would not be appropriate to review all of this information in detail. Much of it remains unpublished and that which is published is widely scattered through the geologic literature. However the general nature and composition of oceanic sediments are fairly well known, and reviews of these topics are available (Murray and Renard, 1891; Shepard, 1948; Beall and Fischer, 1969; Weser, 1971; Pimm, Garrison and Boyce, 1971; etc.). There would seem to be little value in yet another descriptive catalogue. The purpose of the present contribution is simply to place the results of deep sea drilling on Leg 12 into the overall context of our present knowledge of North Atlantic sediments. Accordingly, we have tried to present only the broad outlines of present information in the hope that those more knowledgeable and with more time at their disposal will one day take the opportunity to assemble a more detailed and extensive presentation.

Each site drilled during Leg 12 of the Deep Sea Drilling Project was drilled in order to obtain information relating to certain specific problems. The sediments sampled at each site have been described and discussed in relation to these problems in the foregoing site reports (Chapters 3 through 10 , this volume). The sediments sampled at each site are summarized in Figure 1. We have endeavored to refrain from repeating detailed descriptions of the sediments. Rather, in this summary chapter we have tried to view the sediments of the northern North Atlantic in terms of the broad processes of sediment distribution.

Nearly all the sediments of the northern North Atlantic between the Gibbs Fracture Zone and the latitude of Iceland have been transported long distances by various mechanisms before being deposited, and the source of the sediment is often difficult to determine. In some fields of sedimentology, for example recent fluviatile sedimentation, the broad provenance of the sediments, the processes of sediment dispersion and deposition and the environment of deposition are well defined. Thus a detailed analysis of the sediment deposits can lead to considerable insight and understanding of their development. Virtually all oceanic sediments however are polygenetic and individual sources of sedimentary material exert a correspondingly less significant influence over the nature of the resultant sedimentary deposit than do the agents of sediment transportation and deposition. In many cases even the traditional distinction between terrigenous and pelagic sediments is of little value in our attempts to understand the pattern of sediment distribution. As will be immediately apparent from the site reports, the details of the nature and composition of the sediments of the northern North Atlantic are complex. This complexity is to be expected. The North Atlantic is surrounded by land masses contributing sediments derived from virtually every known rock type and ranging from Precambrian to Recent in age. This region of the ocean, because of its geometry and geographic location, is oceanographically and biologically complex leading to a corresponding complexity of distribution of pelagic material. Thus it follows that the key to understanding sedimentation in the northern North Atlantic lies in viewing the sediments in terms of the processes of transportation and deposition. Once a working model has been developed it may become possible, through a detailed study of more drilled cores from more sites, to unravel the many strands brought together by the processes of transportation and thus by successive refinements, to develop the type of comprehensive model which can now be constructed for less subtle and less complex sedimentary situations.

Sediments are transported from their source either by currents while suspended in water, or by winds while airborne and then by currents. A less important contribution comes from chemical deposition from the bottom water. The currents can either be driven by forces independent of the sediment load (for example, horizontal gradients in the potential density due to salinity and temperature, wind stresses, tides, etc.) or by gravitational forces depending on the density increases caused by the sediment load.

Depending on these factors and on the prime source of the sediments we can distinguish three categories of sediment transportation mechanisms.

(a) Turbidity currents driven by excess density due to suspended sediment (usually, but not always, terrigenous).

(b) Deep ocean and bottom currents which are part of the normal ocean circulation, carrying sediment of all types (mostly fine).

(c) Surface and near surface currents, mostly wind driven, which transport the living biomass which is concentrated in the euphotic zone, and fine terrigenous sediment. They also control ice-rafted sediments.

It should be emphasized that this list is by no means all inclusive, but serves only to present the broad scale, major processes as a basis for discussion. We have not discussed, for example, secondary processes of sediment distribution, such as small scale reworking. 


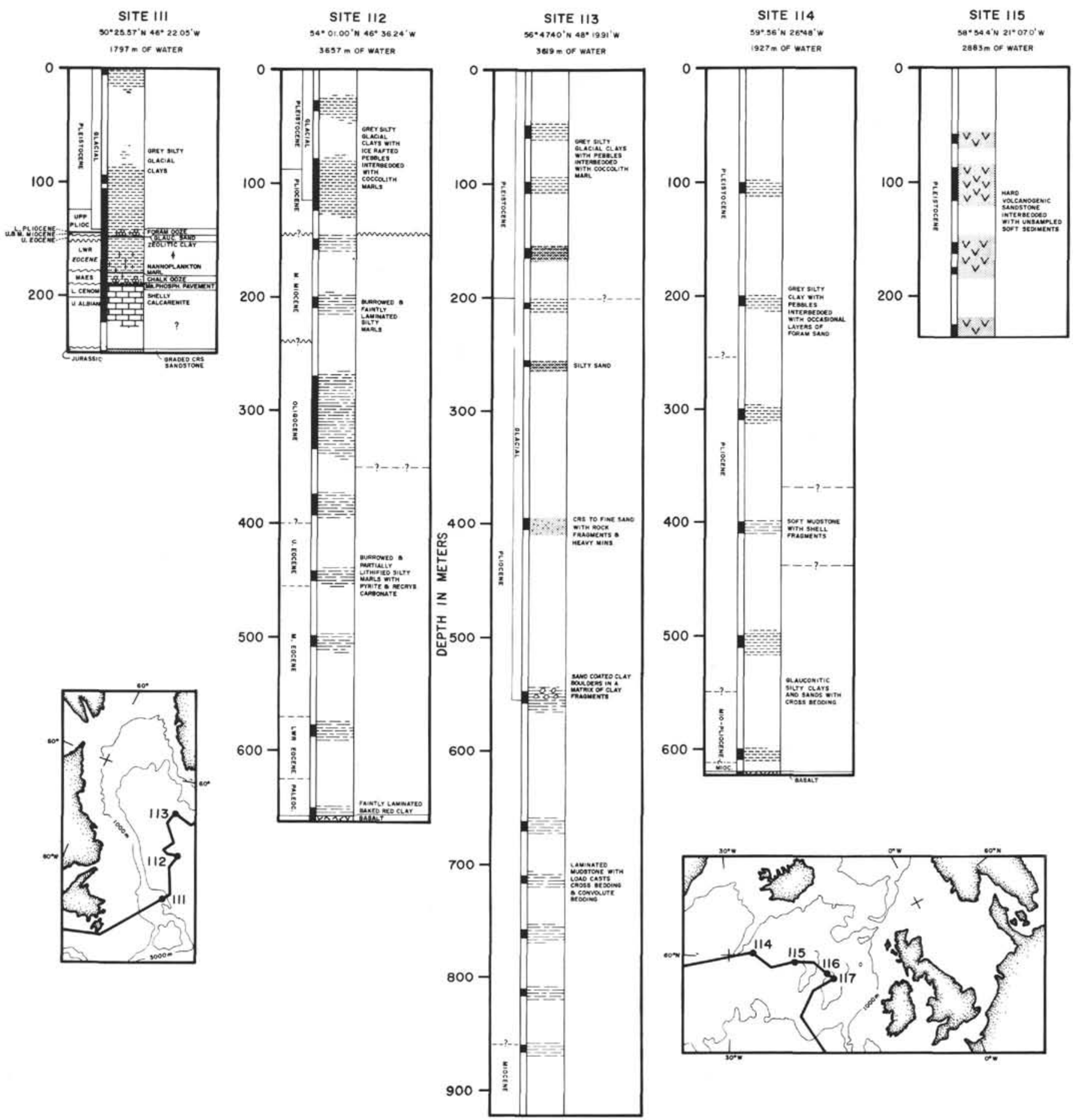

Figure 1. Summary of stratigraphy of sites drilled on Leg 12.

The sediments sampled on Leg 12 provide some excellent examples of the results of the action and interaction of these various processes. In addition, sediments from shallow water environments were sampled at two sites. These various topics will be discussed in turn.

\section{TURBIDITY CURRENTS}

Attempts in the early nineteen fifties to explain deep-sea sand layers in terms of strong bottom currents were probably the first serious challenges to the concept of a quiet, nearly motionless deep sea floor, so widely accepted up to that time. The existence of these sand layers, the discovery of submarine canyons cutting many of the continental margins of the world and the occurrence of sudden breaks in submarine cables, led to the concept of turbidity currents as significant agents in deep-sea sedimentation. The reader is referred to the works of Kuenen $(1937,1951,1964,1966)$, Heezen (1959, 1963 ) and Heezen and Laughton (1963) for a general introduction to the concept of turbidity currents and their role in deep-sea sedimentations. This concept, though occasionally 

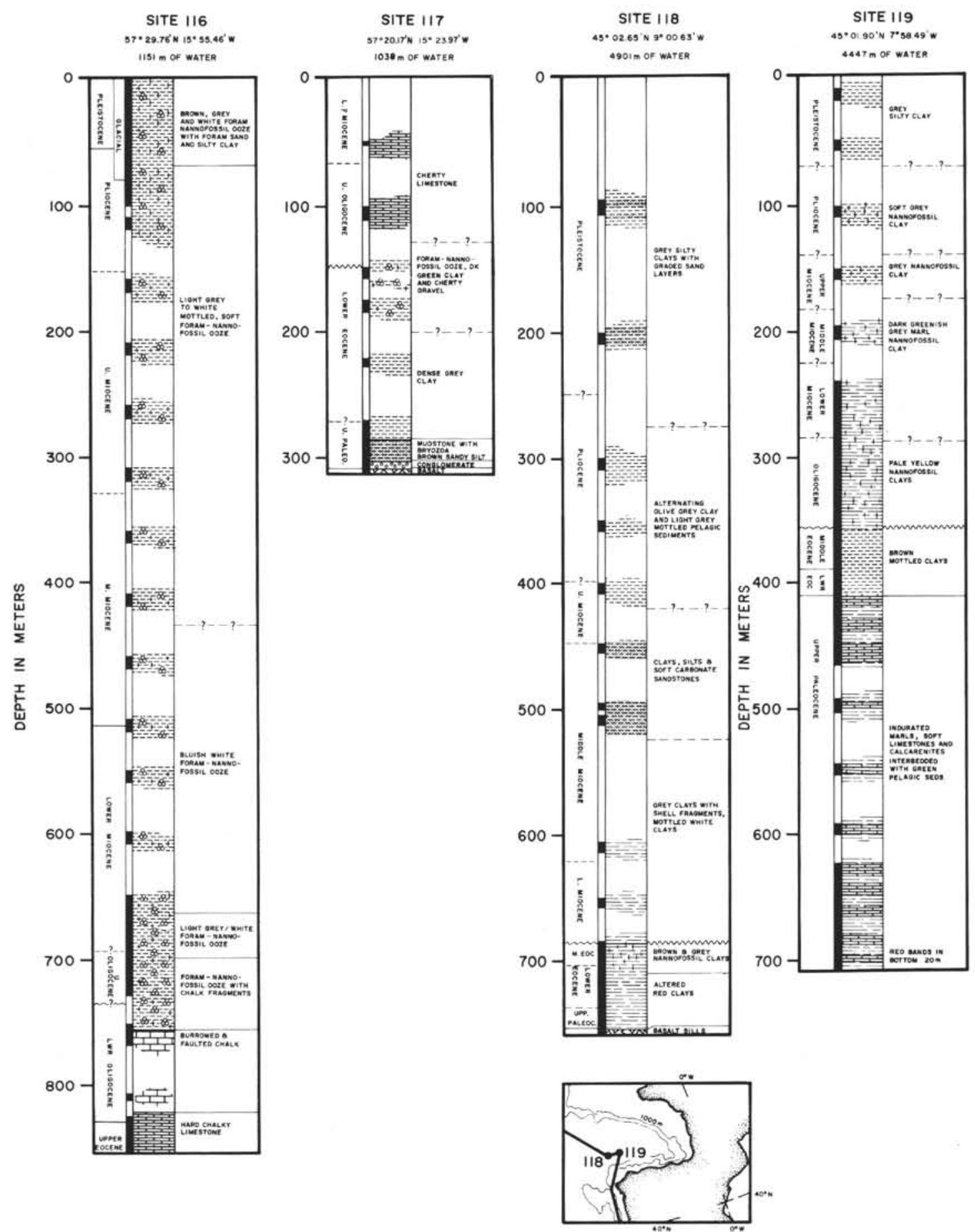

Figure 1. (Continued)

overworked, is now generally accepted and will not be discussed here.

Turbidites were sampled at four of the sites drilled on Leg 12 , Sites $113,115,118$ and 119 . The deposits were recognized as turbidites from the following characteristics:

(a) They form discrete beds with a well-defined base and a gradational top. Often they contrast strongly in color and other physical properties with sediments deposited in other ways. (b) The beds are usually graded from coarse at the base to fine at the top. In some cases lamination, parallel and convolute, was seen, especially in the upper parts. Burrowing was found only in the uppermost part of the beds. Figure 2 and Plate 1 illustrate these textural and structural characteristics.

(c) Shallow water and/or terrigenous material is abundant in the beds and absent or rare in the intervening layers of sediment. 


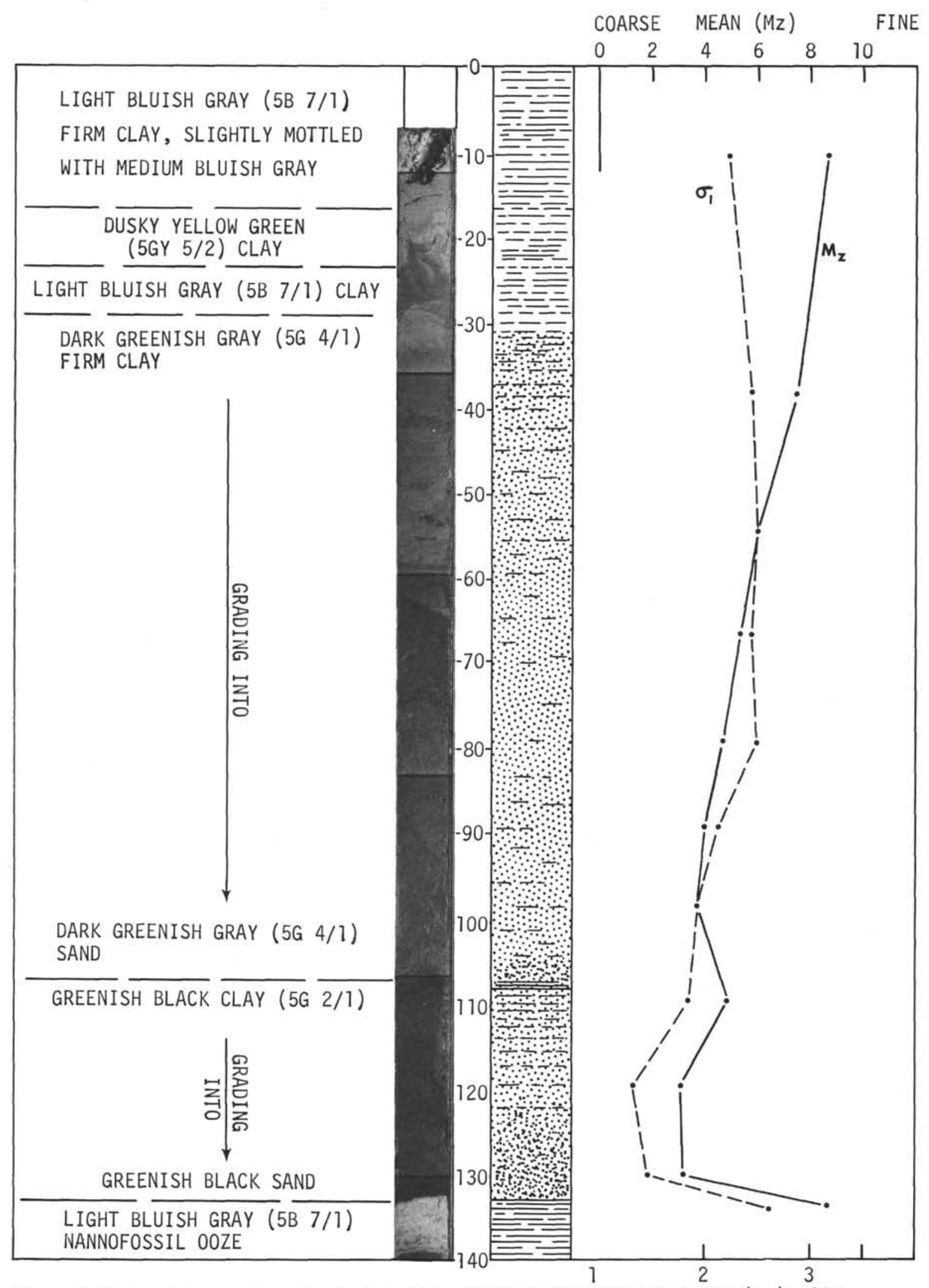

Figure 2. Textural changes through a single turbidite (118-2-6) MODERATE SORTING $\left(\sigma_{I}\right)$ POOR 
(d) On the echo-sounder records and seismic profiles, the turbidites are characterized by:

(i) high sea bed reflectivity (giving rise to sea bed multiples),

(ii) strong stratification,

(iii) flat beds and absence of waves and ridges; sediments appear to have been ponded in regional depressions.

In the Labrador Sea (Figure 12) stratified sediments lie around the outside of a semicircle of basement ridges which bounds a large body of bottom current deposited sediment which will be discussed later. The stratified sediments have been deposited lapping onto and over this sediment body. The boundary between these sediments and the bottom current deposited sediments can be easily seen on seismic profiles (Figure 9) and echo-sounding records. The distribution and appearance on the profiles of these sediments are typical of those which might be expected to be deposited by turbidity currents derived from the neighboring continental margins, both of Greenland and of Labrador.

The results of Hole 113 confirmed this interpretation. The sediments were terrigenous clays, silts and sands with rock fragments and heavy minerals. Turbidite beds were seen and there was also evidence of mud flows carrying Eocene clasts in a Pliocene matrix. Extremely high sedimentation rates $(10-20 \mathrm{~cm} / 1000$ years) reflected the large source area for terrigenous sediments. The hole penetrated to 923 meters but did not obtain sediments older than ? Miocene. Although the Eirik Ridge does not reach as far south as Site 113, small channels run southwards from its southern end and undoubtedly bring further sediments from east of Greenland into the area of Site 113 first by bottom currents and then by local turbidity currents, contributing to the high sedimentation rate.

At Site 115 also, the sediments were relatively young. At this site the reflection records showed an extremely strong reflector just beneath the sediment-water interface, stronger than the bottom echo. Drilling produced samples of hard volcanogenic sandstone interbedded with soft sediments which were unsampled except for odd lumps and smears caught between the hard rock fragments. It was apparent from the drilling that we were in fact penetrating a succession of sandstone beds each one only a few meters in thickness. These sandstones are composed of the eruptive products of underwater or underice volcanoes transported by turbidity currents, probably from Iceland. Flash floods, or jokulhlaups, carrying large quantities of hyaloclastites from sub-ice volcanism, were common in Iceland during the Quaternary. The cores often show graded-bedding, horizontal and cross lamination, slump structures, and they contain some shallow water benthonic foraminifera and molluscs. They were sampled to a depth of 228 meters.

The areal extent of the sandstone layers can be inferred from geophysical data. Seismic profiles by Vema and Discovery suggest that they extend over 100 kilometers west from the base of Hatton Bank. The Maury mid-ocean canyon, running south from the Iceland Faroes Ridge, widens considerably as it cuts down to the top of the first sandstone layer, but 150 kilometers south of the site, it narrows again where, perhaps, the sandstone stops. To the east of the site, the layers abut against the foot of the west scarp of Hatton Bank, suggesting that the source is not located there. A natural course for the eruptive products of Icelandic volcanoes would be through the canyons south of Iceland to the deepest part of the Iceland Basin between Hatton Bank and the Reykjanes Ridge.

In the Bay of Biscay, at Sites 118 and 119, older turbidites were sampled, in addition to those of Pleistocene age. Site 119 yielded samples of Paleocene turbidites composed of shallow water (?) carbonate debris with re-worked Cretaceous coccoliths, and Site 118 yielded Miocene and Pliocene turbidites of detrital carbonate and Pleistocene turbidites of mixed terrigenous debris. The relationship between the older turbidites at these sites and tectonic events in the Bay of Biscay region has been referred to in the discussion of the Biscay region and will be discussed again later. The Pleistocene turbidites are typical detrital sands such as have been described from abyssal plains all over the North Atlantic (Heezen and Laughton, 1963).

The relationship between turbidites and abyssal plains is now widely accepted. It is also becoming clear that turbidity current activity in the North Atlantic is not unique to the Pleistocene, but is a process which has probably been going on to a greater or lesser extent throughout the history of the North Atlantic. Deep sea drilling has produced samples of turbidites ranging in age from Upper Cretaceous to Recent (Ewing et al., 1969; Peterson et al., 1970; this volume). The formerly widespread notion that turbidites were a comparatively insignificant ocean sediment type except during the PlioPleistocene glaciation therefore probably stems from the inadequacy of our samples and the apparent preponderance of sandy turbidites in the Pleistocene record in the deep sea. The coarseness of the turbidites, of course, is a function of sediment supply so that an abundance of sandy turbidites is to be expected during the glaciation, a time of lowered sea level, or during times of tectonic disturbance.

On the assumption that the abyssal plains are the sites of turbidite accumulation, we can combine the data from Leg 12 with that of earlier investigators (Ericson et al., 1961; Heezen and Laughton, 1963) to define areas of the North Atlantic where turbidity currents have been a dominant influence on sedimentation through the Pleistocene. This has been done in Figures 3 and 17.

\section{DEEP OCEAN AND BOTTOM CURRENTS}

The existence of bottom currents in the deep oceans has been known for some time, but the fact that these currents were of any geological significance has only lately been acknowledged (Heezen, 1959; Heezen and Hollister, 1964). More recent studies have led to the realization that bottom currents in fact have a very profound influence on the distribution of sediments on the ocean floor. This was first demonstrated through careful studies of the continental rise off the eastern United States which showed that the rise has been shaped by deep, contour-following, geostrophic currents (Heezen, Hollister and Ruddiman, 1966; Schneider et al., 1967; Hollister and Heezen, 1967). From these studies it became apparent that in this region, and probably in many regions of the world ocean, the deep water and 


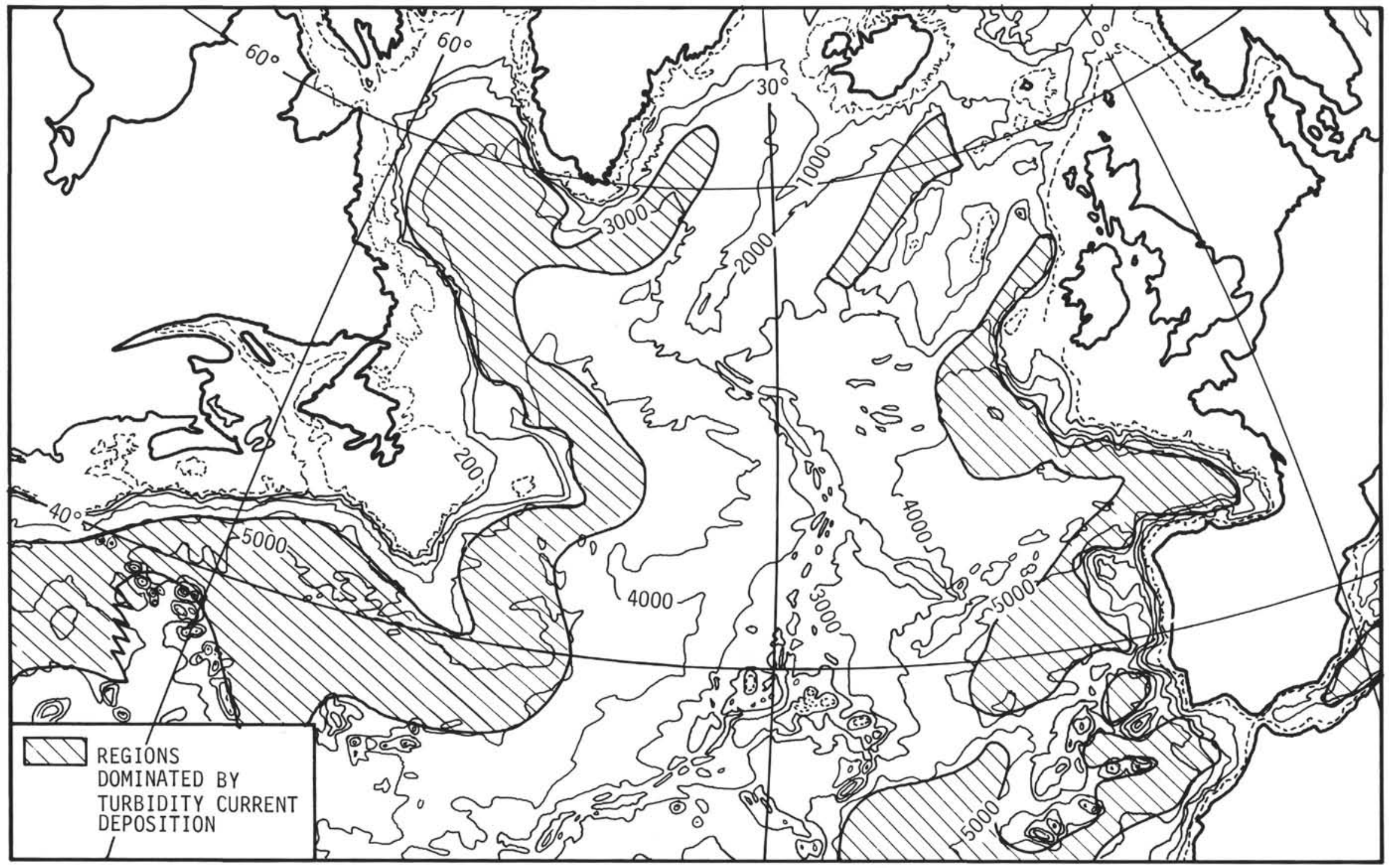

Figure 3. Regions in the northern North Atlantic where sediment distribution by turbidites is significant. 
bottom currents were significant agents in transporting fine sediment. Where the currents were slowed down by contact with an adjacent water mass moving with a different velocity they lost their competence and deposited their sediment load. This has perhaps been most elegantly demonstrated in the case of the Blake-Bahama Outer Ridge, which Bryan (1970) and Markl et al. (1970) have suggested is the consequence of the interaction of the Gulf Stream and the Western Boundary Undercurrent. Sediment deposition would also be expected, in the less complex case of the interaction of a bottom current and a relatively static water mass (Figure 4) and we might expect the development of long, narrow sediment ridges parallel to the currents. Note that the sediment would not accumulate under the center of the current but at the margins of the flow. Where the currents encounter major solid obstacles, such as a seamount, they would speed up and reduce the sedimentation rate or even may start eroding the sea bed, producing a characteristic moat (Heezen and Johnson, 1963; Johnson, Vogt and Schneider, in press; Weser, 1970), or marginal channel (Figure 5). Figure 6 shows examples of these features from the Glomar Challenger, Leg 12 records. Under some conditions, where the current is not banked against a steep topography, interaction between the current and the adjacent stationary water may happen on both sides, and twin ridges might develop (Figure 7).

The next major step in the recognition of the significance of bottom currents in sediment distribution in the North Atlantic came when it was noted from seismic reflection records that in several places in the North

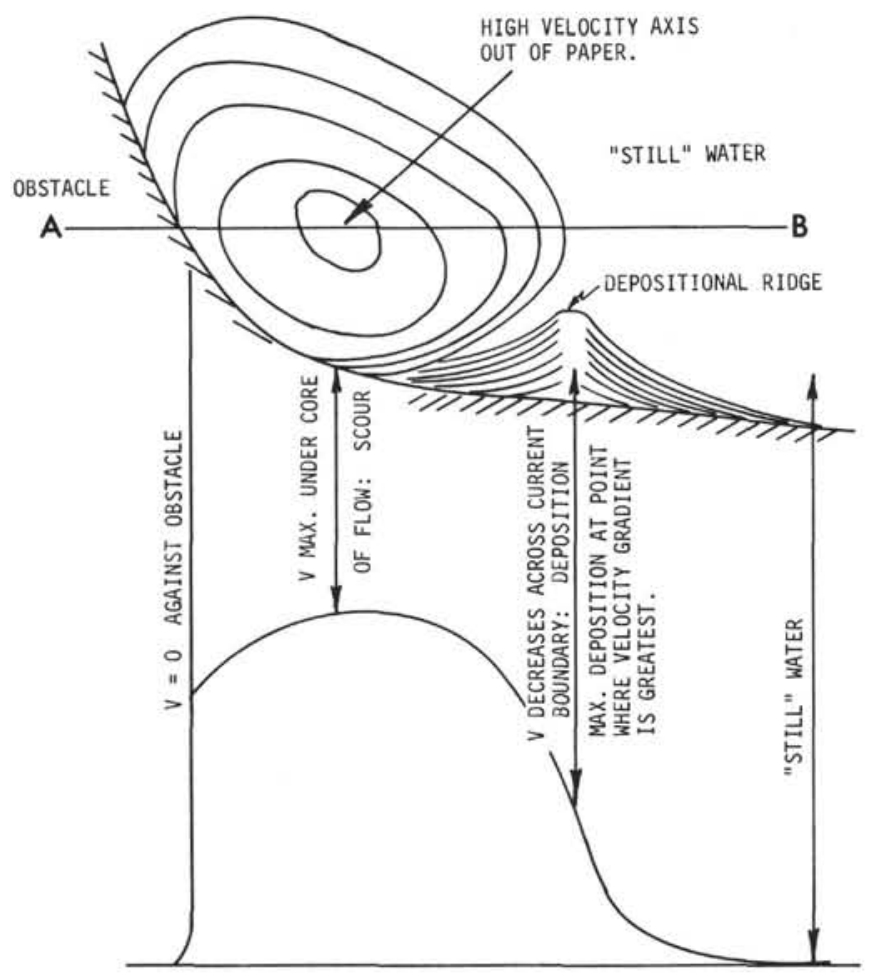

FLOW VELOCITY PROFILE ACROSS AB

Figure 4. The formation of depositional ridges by bottom currents.
Atlantic there were in fact long ridges composed of thick piles of sediment (Johnson and Schneider, 1969; Jones et al., 1970). The Feni Ridge lies along the east side of Rockall Bank, the Gardar Ridge runs down the east side of the Reykjanes Ridge and the Eirik Ridge extends southwest from the southern tip of Greenland (Figure 17).

The present day deep-water circulation of the North Atlantic (Figure 8) has received considerable study from European and American oceanographers, and Johnson and Schneider (1969) and Jones et al. (1970) were able to relate the sediment ridges to the known deep water circulation in the region. It is clear that high salinity overflow water from the Iceland-Faroes Ridge (Worthington, 1970) travels southwest both along the eastern side of Rockall Bank (producing the Feni Ridge) and along the eastern side of the Reykjanes Ridge below about 1500 meters ( 800 fathoms) (producing the Gardar Ridge) and that much of this passes through the Gibbs Fracture Zone (Worthington and Volkmann, 1965) to travel northwards up the western side of the Reykjanes Ridge and then south along the eastern continental margin of Greenland (producing the Eirik Ridge). The currents show a very clear tendency to lie along the west side of the basins through which they flow. This is the simple effect of Coriolis' force which tends to swing a current to the right (in the northern hemisphere), and hence guides the current along bathymetric contours; however, other forces, such as potential density difference and the reaction to other moving water masses, can control the path of the current and it may not always follow a contour. For this reason the phrases "contour current sediments" and "contourites" are avoided here.

The identifying characteristics of sediment deposits formed under the influence of bottom currents seem to be as follows:

(a) The sediments are relatively transparent (acoustically) lacking the strong internal layering which often characterizes turbidite deposits (Figure 9).

(b) The sediments are not uniformly distributed in relation to the basement topography (cf. pelagic sediments discussed later), but are often heaped into piles and ridges elongated in the direction of the bottom current and lying under the margins of the current (Figure 10b).

(c) Where the sediment bodies encounter basement highs there is typically a marginal channel or moat and the sediments are seen to thin and dip towards the obstacle (Figure 6).

(d) The upper surface of the sediment bodies is commonly wavy with a typical wavelength of 2 kilometers and an amplitude of 50 meters (Fox and Heezen, 1968) (Figure 11).

On Leg 12 we sampled sediments which we believe to have accumulated under the influence of bottom currents at three sites: 112, 114 and 116. These cores and the reflection records gathered by the Glomar Challenger have added some more details to our picture of sedimentation in the North Atlantic. The sediment bodies sampled at Sites 114 and 112 will be discussed first. We will then describe briefly what is known of deep ocean and bottom currents in adjacent regions of the North Atlantic in order to give a more coherent picture.

Banked up against the eastern flank of the Reykjanes Ridge is the bottom current deposited Gardar Ridge 


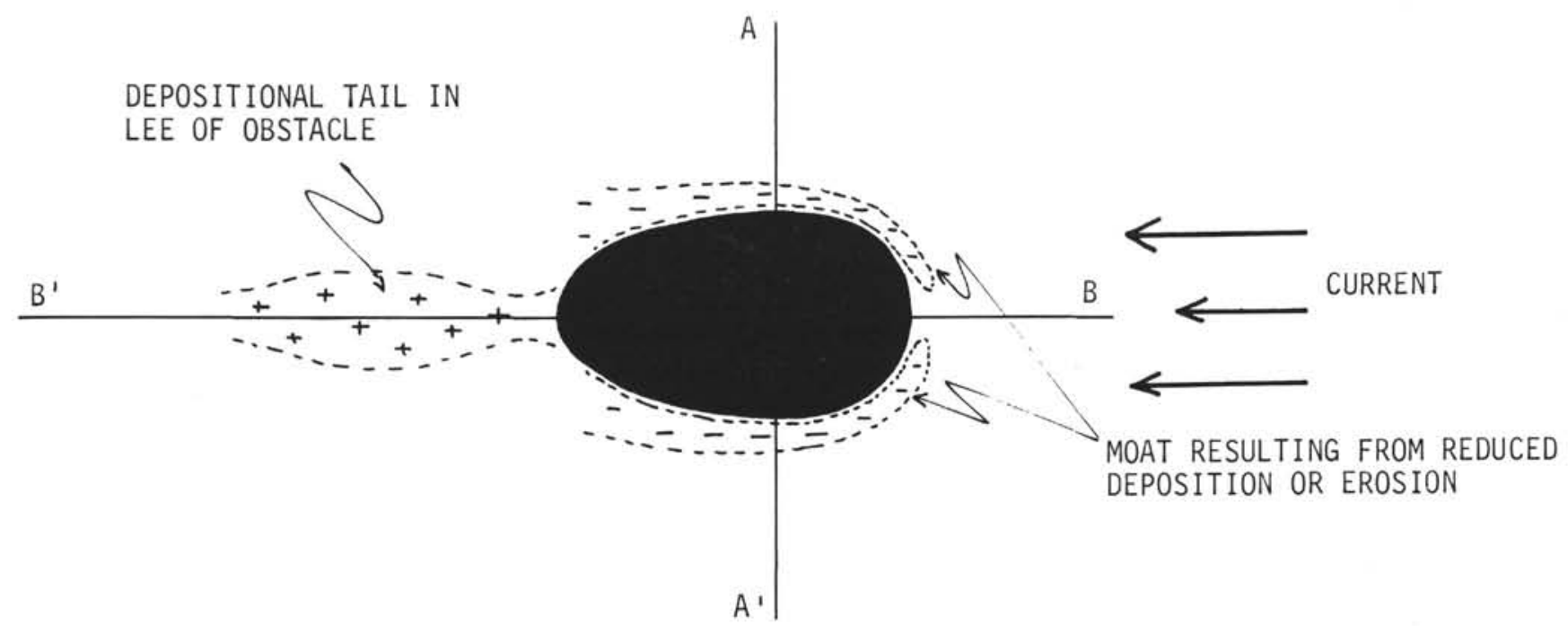

MOAT: REDUCED DEPOSITION OR EROSION
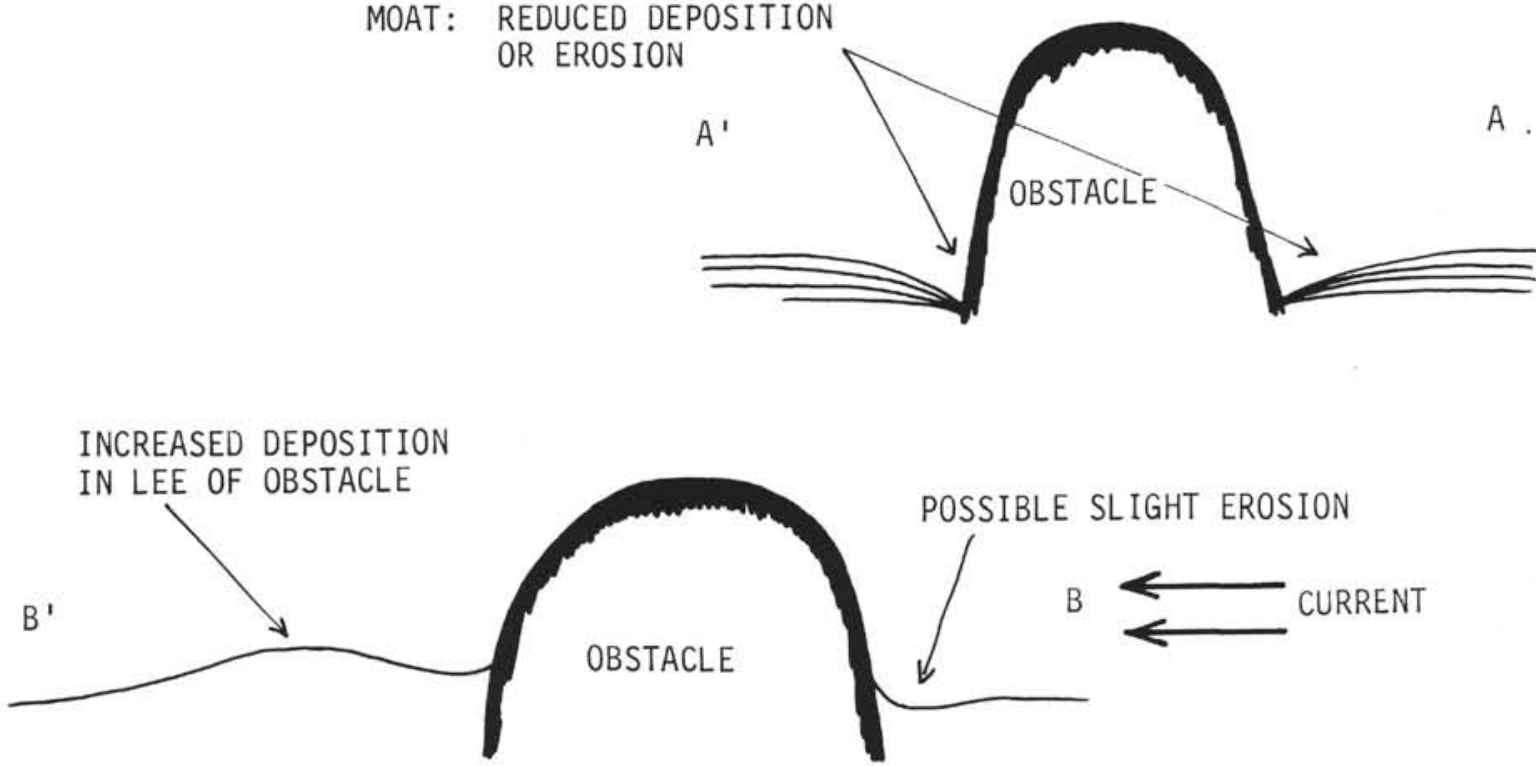

Figure 5. The formation of moats by bottom currents.

(Johnson and Schneider, 1969). The western boundary of this coincides approximately with magnetic Anomaly 12 and an associated steep scarp in the subbottom topography (Figure 10a). Two profiles by Vema-27 across the Gardar Ridge and two just north of the Gibbs Fracture Zone at $27^{\circ}$ and $30^{\circ} \mathrm{W}$ show a sediment body with a mid-sediment reflector similar in character to that in the Southern Labrador Sea.

To the west of the Gardar Ridge, towards the crest of the Reykjanes Ridge, the sediments are still of considerable, but variable, thickness until they thin abruptly to about 0.3 -second thickness just below the 1000-fathom contour. This "sediment discontinuity" has been interpreted as the result of either a hiatus in sea-floor spreading or preferential accumulation of sediments by bottom currents. Since the Gardar Ridge was known to be the result of bottom currents the latter hypothesis seemed more reasonable, and Site 114 was drilled to test this idea. All the sediments were found to consist entirely of clayey silts of the same heterogeneous composition. The cores were essentially structureless, except for a suggestion of faint lamination and, in Core 6, some cross-bedding; the sediment was shown to have accumulated quite rapidly (sedimentation rate is $12 \mathrm{~cm} / 1000 \mathrm{yr}$ ). A Discovery II hydrographic profile (Figure 10a) shows that the south-westerly flow of the Norwegian Sea overflow water is banked up to as shallow as 1000 meters (550 fathoms) (Fuglister, 1960); and this leads to the conclusion that probably all sedimentation below that depth on the eastern flank of the Reykjanes Ridge is under the control of this movement of bottom water. The seismic profiles referred to above, together with the Glomar Challenger profile, suggest that the sediment body covering the ridge flank is in fact divided into two or more branches of which the Gardar Ridge is the widest, whereas, that at Site 114 is more sharply defined. Site 114 lies on the western branch (see Figure 17). Bearing in mind that, although Coriolis' force tends to force the bottom water to the right of the trough (that is, to the west) 
0

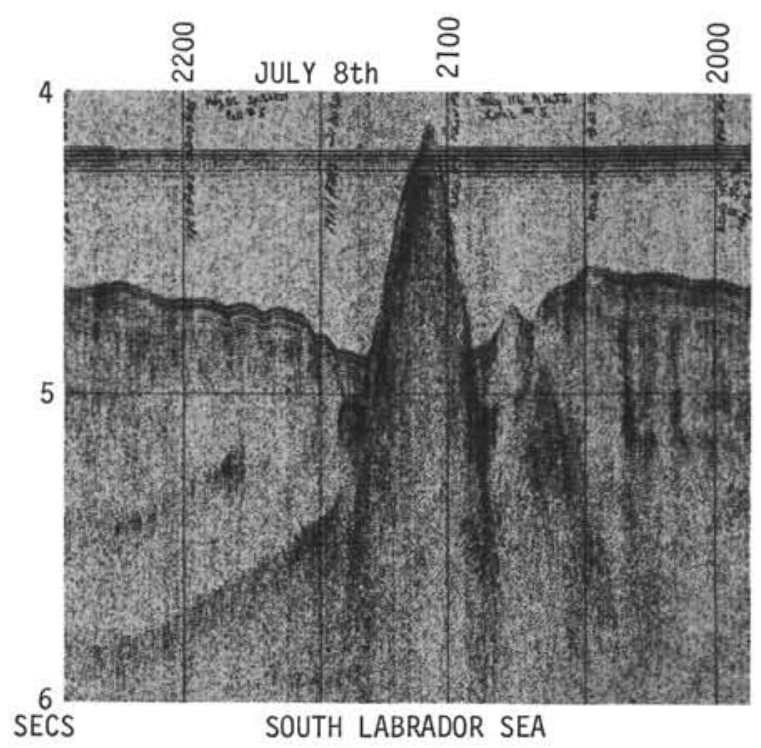

0

20

$40 \mathrm{KM}$

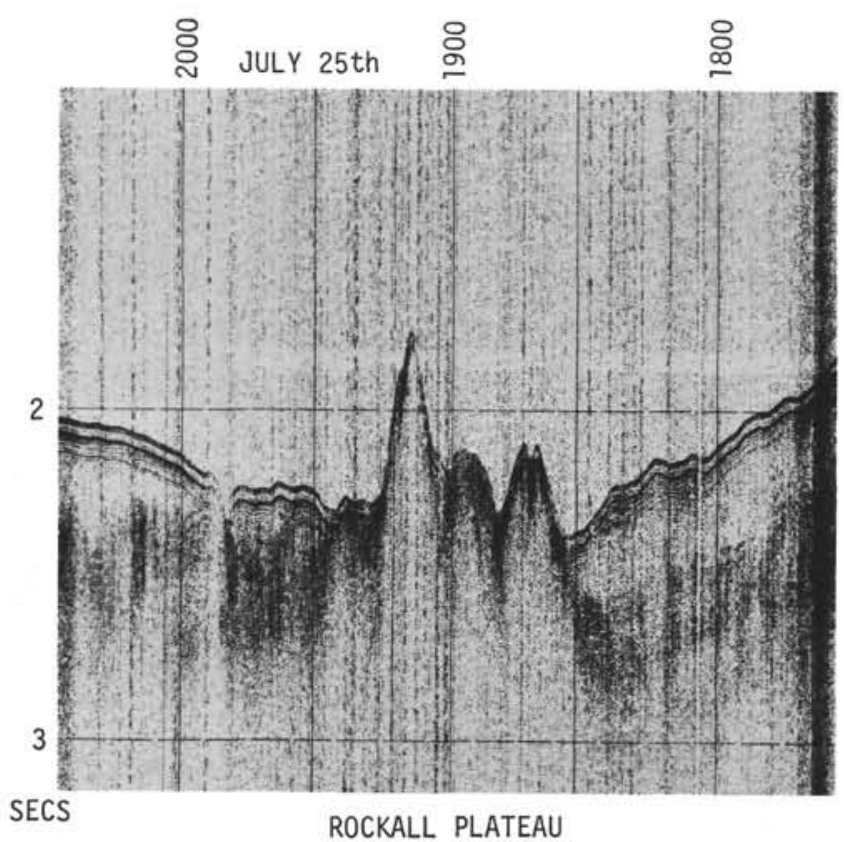

Figure 6a. Examples of moats from seismic reflection profiles by Glomar Challenger-12.

between Reykjanes Ridge and Rockall Plateau, actual sediment deposition will be maximum where the velocity of the water changes abruptly, thus the bifurcation of the sediment body and the location of the ridges on either side of the flow of bottom water is to be expected (Figure 7). If $\stackrel{20}{0} \quad 40 \mathrm{KM}$

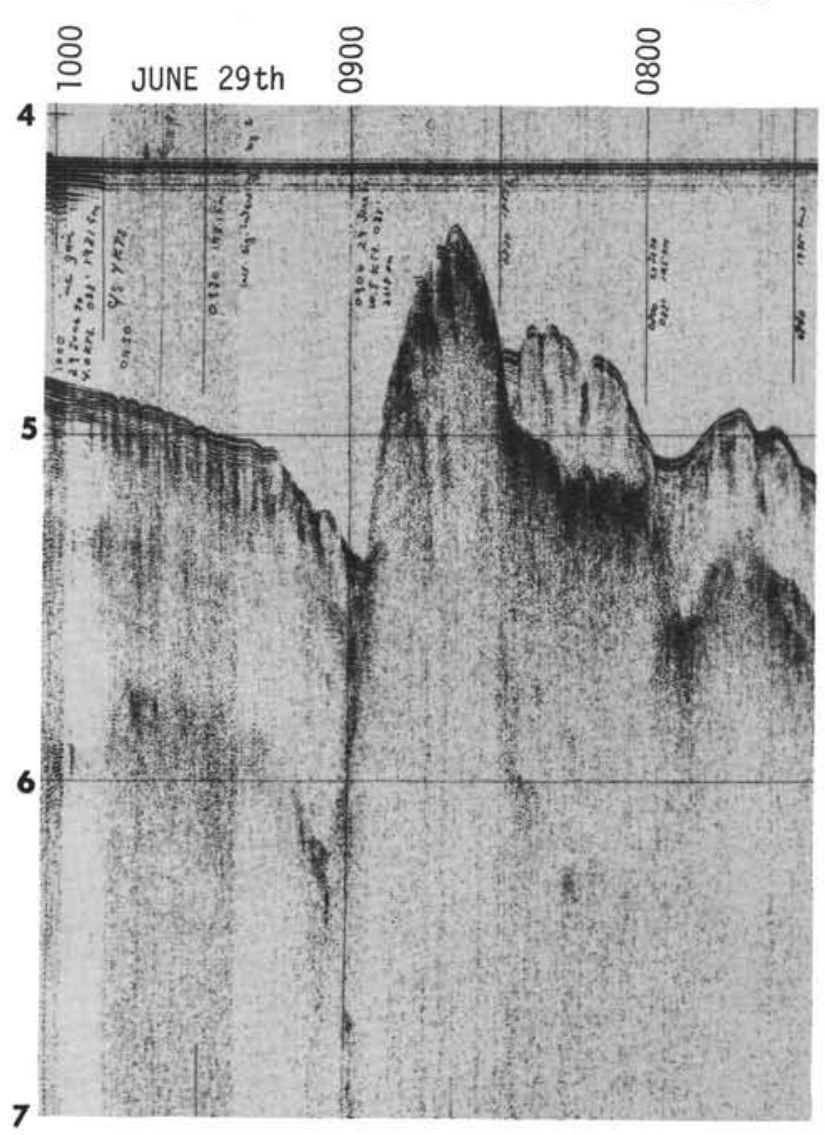

SOUTH LABRADOR SEA

Figure 6b. Example of marginal channel from seismic reflection profile by Glomar Challenger- 12 .

the bottom current itself is divided into several streams, then more ridges will result. One further result from Site 114 which deserves note is that the bottom of the sediment pile was approximately at the Pliocene/Miocene boundary, revealing that the current regime in this region has been essentially constant for the past 6 million years.

Worthington and Volkmann (1965) have demonstrated the westerly transport of Norwegian Sea overflow water through the Gibbs Fracture Zone into the West Atlantic, after traveling down the east side of the Reykjanes Ridge. On the basis of bottom topography and sediment distribution in the Fracture Zone, Le Pichon, Eittreim and Ewing (1971) have inferred an east going bottom current below 3000 meters, although recent measurements with current meters (Garner, in press) show that at present it is flowing westwards. Sediments carried by the Norwegian Sea overflow water can therefore reach the southern Labrador Sea.

The thick body of sediments lying in the Southern Labrador Sea (Figures 9 and 12) was sampled at Site 112. The sediments are relatively transparent, one prominent but rather diffuse mid-sediment reflector being seen over the whole area. Neither the reflector nor the upper surface conform with basement topography, and the sediments 


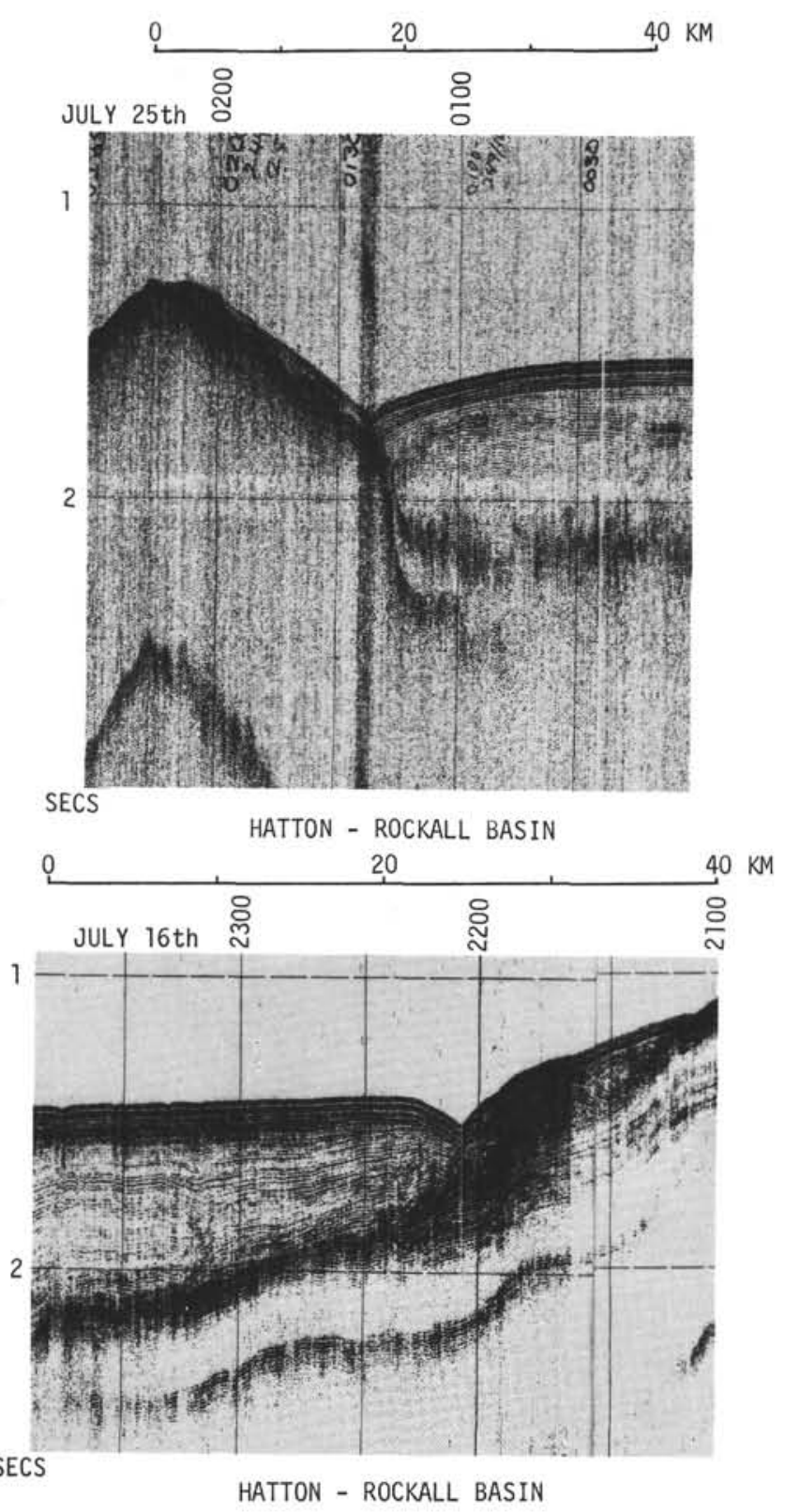

Figure 6c. Examples of marginal channels from seismic reflection profiles by Glomar Challenger- 12 .

show all the characteristics of having been deposited under the influence of bottom currents.

The sediment body appears to be more or less confined by a semicircle of basement ridges (see Chapter 20) but overflows and thins to the west and south where it dips under the stratified terrigenous sediments from the continental margins. The upper surface of the sediment body is commonly wavy but on a larger scale is formed into long ridges (Figure 12).

The sediment ridges suggest that the sediment-laden water flows into the area from the east between $56^{\circ}$ and $57^{\circ} \mathrm{N}$. A well-developed ridge lies between the basement ridges flanking the median valley at $57^{\circ} \mathrm{N}, 44^{\circ} \mathrm{W}$, another between the two southerly ridges and a third to the south. All are deflected to the left in the vicinity of the NE-SW

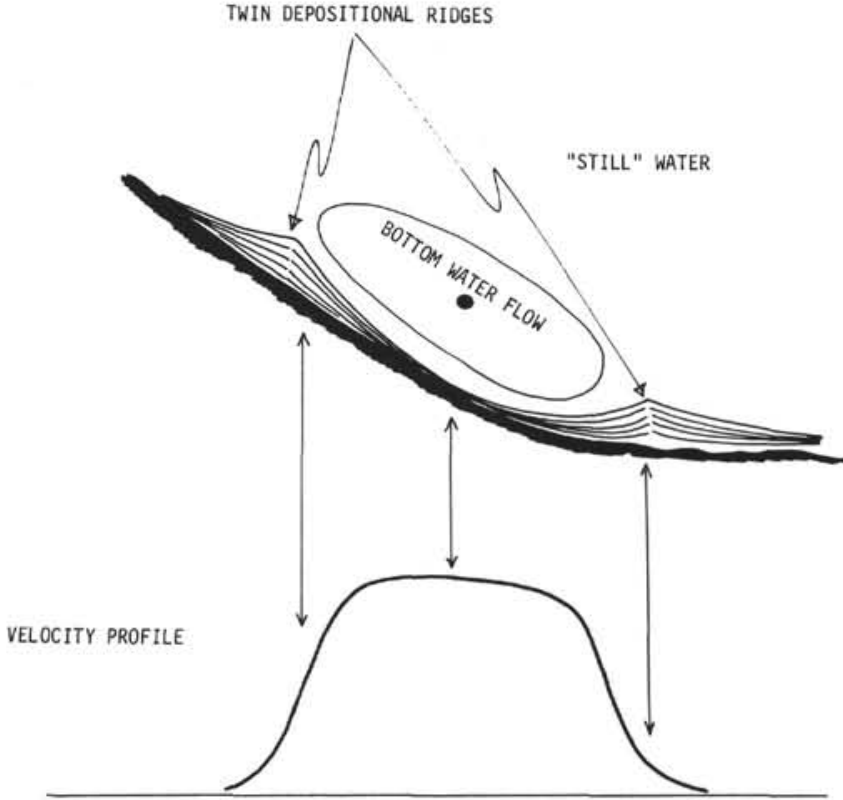

Figure 7. Suggested mechanism for the formation of double depositional ridges.

transform fault running between $57^{\circ} \mathrm{N}, 45^{\circ} \mathrm{W}$ and $55^{\circ} \mathrm{N}$, $48^{\circ} \mathrm{W}$ and again by the ridge near Site 112 . The sequence is bounded to the south by the Gibbs Fracture Zone which possibly has again deflected the flow to the left (that is, to the east). This however is less certain since the bathymetric control of the sediment surface is poor. It is also possible that the sediments shown on the Vema-27 profile north of the Gibbs Fracture Zone have in fact traveled westwards and given rise to the poorly defined bathymetric spur indicated in Figure 12. In this event, it must be assumed that the currents become non-depositional as they travel southwards round the western end of the Gibbs Fracture Zone. It is in this area where the sediment sequence thins and plunges beneath stratified continental sediments (Figure 9).

Evidence from physical oceanography supports these conclusions. Much of the high salinity overflow water from the Iceland-Faroes Ridge traveling southwest along the eastern side of the Reykjanes Ridge, passes through the Gibbs Fracture Zone (Worthington and Volkmann, 1965) to travel northwards up the western side of the Reykjanes Ridge. At $54^{\circ} \mathrm{N}$, the northward transport on the western side of the ridge is $7.6 \times 106 \mathrm{~m}^{3} \mathrm{sec}^{1}$ and at $59^{\circ} \mathrm{N}$, it is $2.0 \times 106 \mathrm{~m}^{3} \mathrm{sec}^{1}$. Whereas some of this difference may be due to temporal fluctuations, or due to mixing with Labrador Sea water (as suggested by Worthington and Volkmann), an alternative explanation is that the greater part of the flow swings westward at $56^{\circ}-57^{\circ} \mathrm{N}$ (due perhaps to topographic barriers) and gives rise to the sediment ridges described.

The flow pattern of sediment laden bottom water would therefore be in the form of an anti-clockwise gyre some 500 kilometers in diameter circulating about a point at about $55^{\circ} \mathrm{N}, 43^{\circ} \mathrm{W}$. Sediment deposited from or redistributed by this gyre could give rise to the sediment body.

Hole 112 sampled all but the bottom 200 meters of this sedimentary body, and the results can therefore be used 


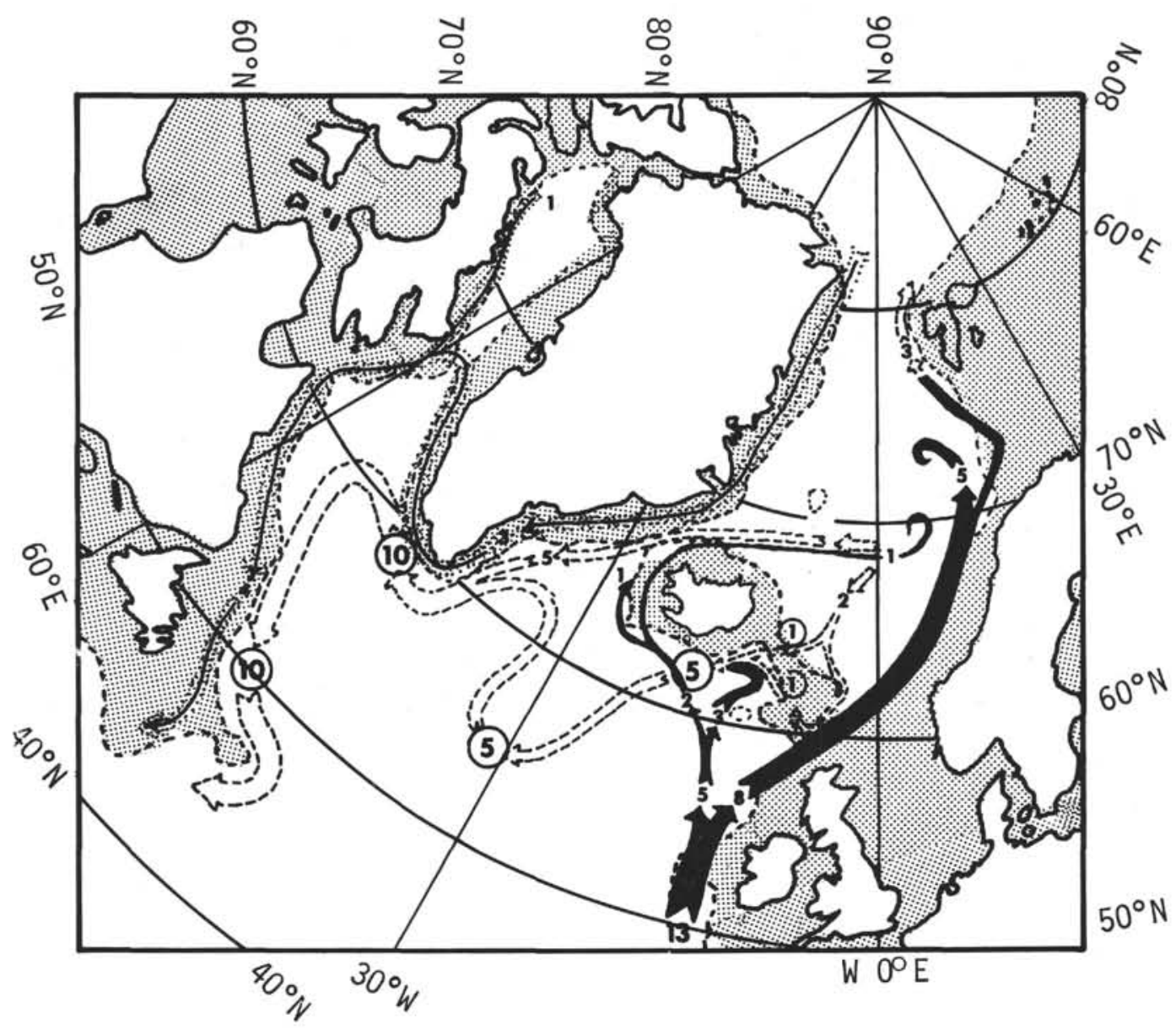

Figure 8. Ocean circulation in North Atlantic showing the balance of transport (in millions of $\mathrm{cu} . \mathrm{m} \mathrm{sec} \mathrm{s}^{-1}$ ) in and out of the Norwegian Sea. Solid black lines: entrained North Atlantic water. Dotted lines: shallow, cold and relatively fresh water and sea ice. Dashed lines: deep Norwegian Sea overflow water (from Worthington, 1970).

to date much of the area. The bulk of the sediments are from Eocene to Pleistocene and by extrapolation of sedimentation rates to the lowest unsampled layers, these should be early Paleocene (63 million years). The midsediment reflector is early Oligocene ( 35 million years). The sediments were all gray clays, silts and marls with some glacial erratic material in the top 120 meters. They appear to be generally finer grained than the sediments found at Site 114 (Figure 13), but since the samples analyzed may not be truly representative of the sediment pile, too much significance should not be attached to this. Further evidence for bottom current activity is to be found in the nature of the diatom faunas (Burckle, this volume). The diatom valves are extensively broken and the faunas have low diversity suggesting transportation and sorting by bottom currents. The calciumcarbonate content of the sediments at both Sites 114 and 112 seldom exceeds 30 per cent. Toward the bottom, partial lithification and recrystallization was found. These observations are consistent with the interpretation of the sediments as current transported pelagic sediments intermixed with fine terrigenous material.

Sedimentation rates for Hole 112 calculated from the stratigraphic ages vary from about $4 \mathrm{~cm} / 1000$ yrs (uncorrected for compaction) in the top 100 meters of the glacial period, to $1.5 \mathrm{~cm} / 1000 \mathrm{yrs}$ (uncorrected) for the bottom 400 meters. In the interval from 100 to 300 meters the mean sedimentation rate is $0.6 \mathrm{~cm} / 1000 \mathrm{yrs}$. These rates are lower than other bottom current ridge rates (for example, Hole 114) but with a considerable area over which the bottom currents can wander, a mean rate of the order of the pelagic sedimentation rate might be expected. Site 112 was near to the marginal channel against the basement high and, hence, in a region where deposition rates would be lower than average due to the acceleration of flow. Sedimentation rates in any one place over the area of this sediment body have probably varied according to changes in the current pattern. If these changes occur with a time constant of the order of tens or hundreds of years, no measurable variations of sediment accumulation could be seen from seismic reflection profiles or from dating of drill cores. If, on the other hand, the changes occur over times of millions or tens of millions of years, significant accumulations could be seen in some places and not in others, and measured sedimentation rates and unconformities would reflect such changes. The existence of ridges several hundred meters high indicates that the flow pattern must have remained constant for periods of the order of 10 million years. In Figure 9, the mid-sediment reflector under 

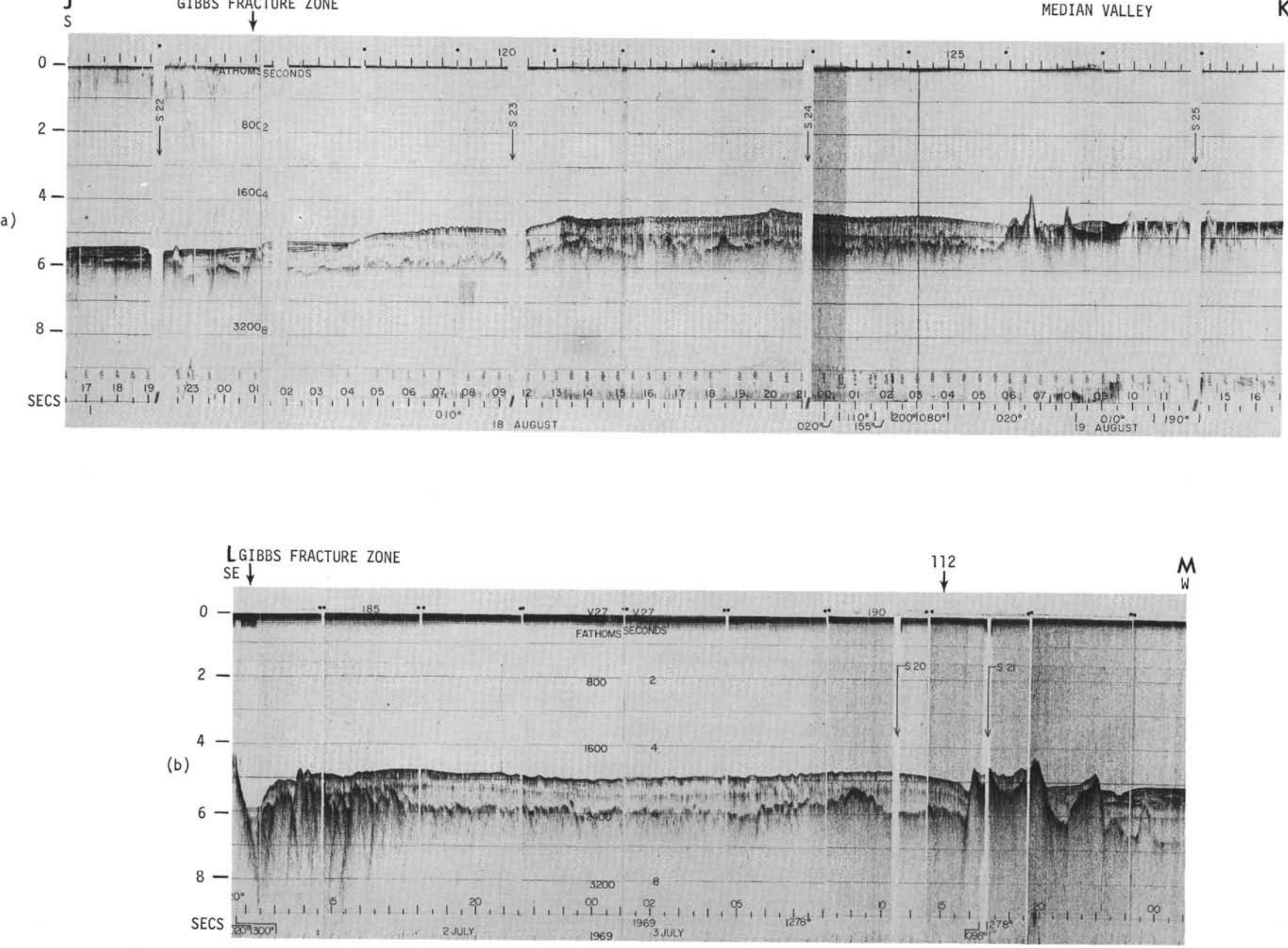

Figure 9. Seismic reflection profiles across the South Labrador Sea (a) by Vema-23 (Jones et al, 1970) and (b) by Vema-27 (by courtesy of the Lamont-Doherty Geological Observatory). The position of profiles is shown in Figure 12. 


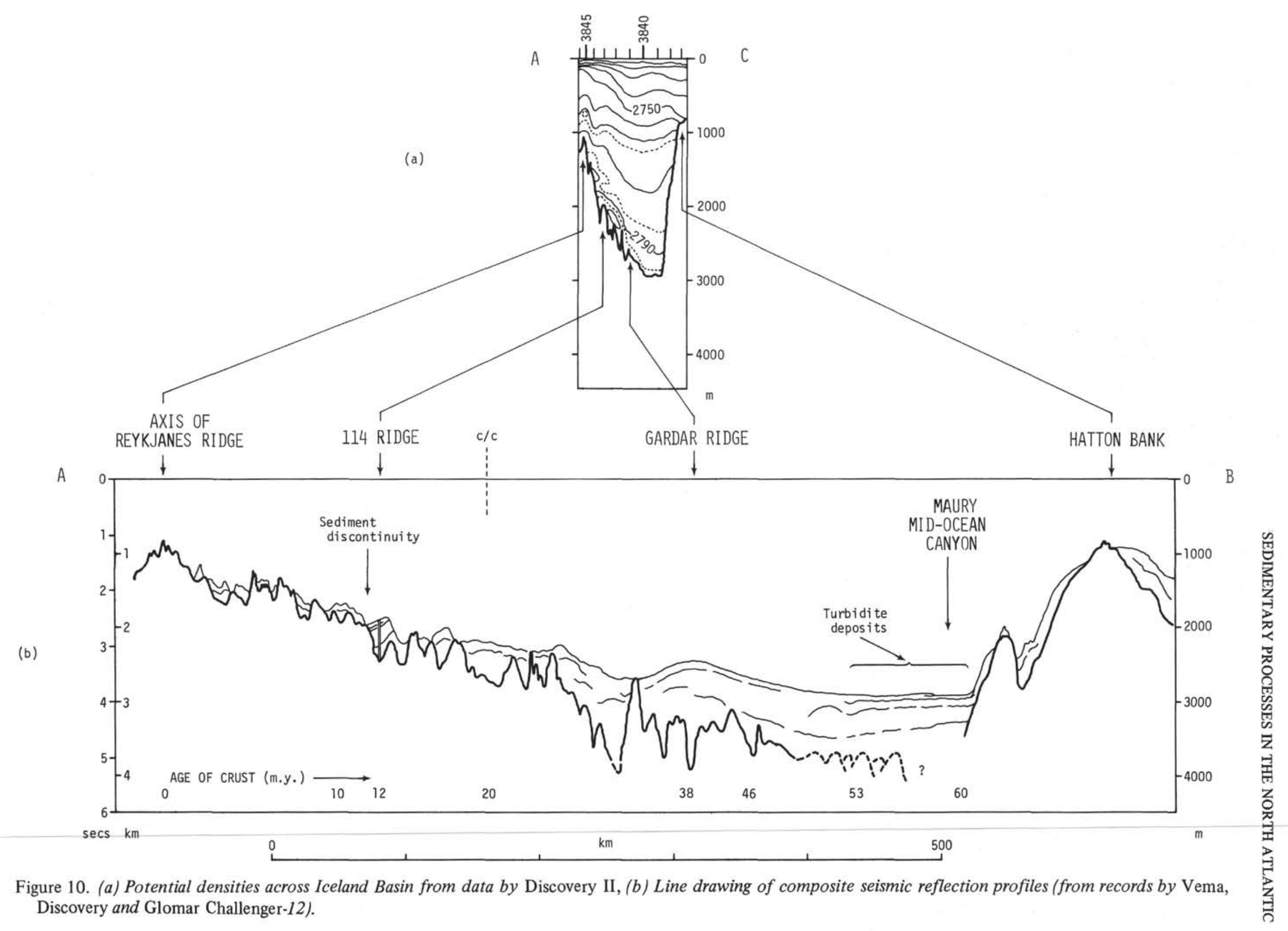




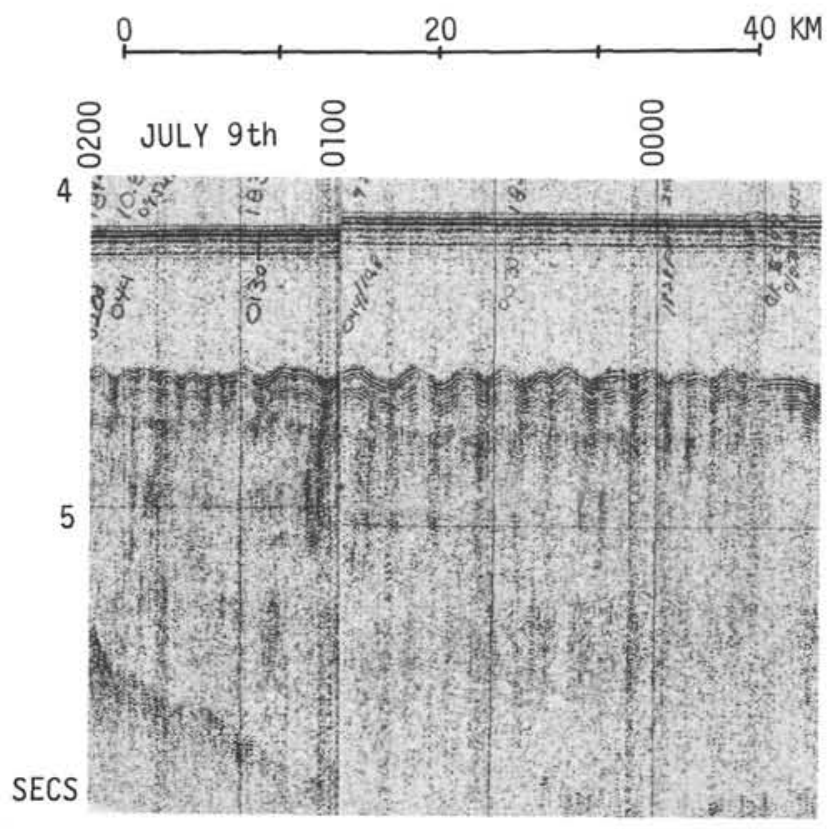

SOUTH LABRADOR SEA

0 20 $40 \mathrm{KM}$

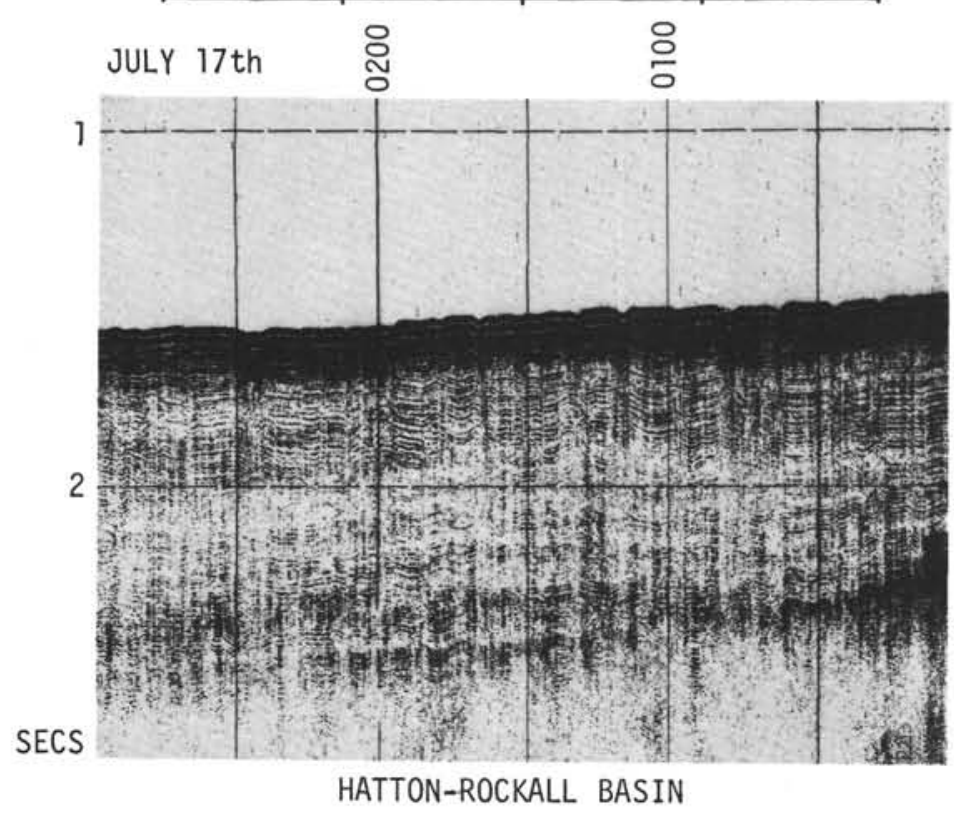

Figure 11. Examples of wavy sediment surfaces on bottom current ridges from seismic reflection profiles by Glomar Challenger- 12 .

the ridge crest is not crested indicating that the present pattern was established later than the Oligocene. However, near Site 112 the internal reflector does dip toward the basement ridge in a similar way to the seabed showing that, at least here, the current pattern has been constant since before the Oligocene.

In the region to the north of the sediment body sampled at Site 112, in the basin between Greenland and the Reykjanes Ridge, a bottom current regime similar to that existing on the eastern side of the Ridge is found.
Worthington and Volkmann (1965) have demonstrated the northerly flow of Norwegian Sea water along the western flank of the Reykjanes Ridge-the northerly transport gradually diminishing as the flow swings westwards to merge with water flowing south from Denmark Strait and forced against the Greenland side by Coriolis' force. Worthington (1969) and Mann (1969) have shown that this is joined by more Norwegian Sea overflow water coming through the Denmark Strait.

It is not possible to say on available data whether the northwest flanks of the Reykjanes Ridge are covered with sediments deposited by the northward flow of Norwegian Sea water. There is, however, an accumulation of sediments, lenticular in cross-section, lying on the continental slope off S.E. Greenland which may be equivalent to the Gardar Ridge, and which is prolonged southwest of Cape Farewell into the Eirik Ridge (Johnson and Schneider, 1969). Jones, Ewing, Ewing and Eittreim (1970) locate the ridge rather differently from Johnson and Schneider, linking the sediment accumulation sampled at Site 112 with the thick sediments at the north end of Vema-17 profile. The bathymetry shown in Figure 12 and the seismic profiles show this to be erroneous. The growth of sediment on the Eirik Ridge is described by Le Pichon et al. (1971). They distinguish pre-Paleocene turbidite sedimentation from the sedimentation above an Eocene/Oligocene reflector by bottom currents sweeping around the southern tip of Greenland. The bathymetry suggests that these bottom currents do not start to swing northwest into the Labrador Sea until they reach $571 / 2^{\circ} \mathrm{N}$. It is clear that these currents bring a considerable quantity of sediments into the Labrador Sea from the Irminger Sea and the Denmark Strait.

In the Northern Labrador Sea, Johnson, Closuit and Pew (1969) have suggested a similar anti-clockwise bottom current system that is fed, in part, by Atlantic water, moulding the sediments of the Northern Labrador Sea. It is difficult, however, to distinguish these sediments from the turbidites from the continental margins.

Turning to the eastern North Atlantic, Jones et al. (1970) have shown the Norwegian Sea overflow water to spill from the Faroes-Iceland Ridge down the eastern side of the Rockall Plateau and give rise to the Feni Ridge (Figure 16). Sediments of the Feni Ridge were not sampled on Leg 12, although the ridge was crossed at its southern end where it curls west around Rockall Plateau (Figure 14). Pronounced waves were seen on the bottom profile. We did however drill in the Hatton-Rockall Basin into what we believe are bottom current deposits (Site 116). The sediments here are white and gray nannofossil oozes with a terrigenous component due to ice rafting in the PlioPleistocene part of the section. The sedimentation rate is high (about $3 \mathrm{~cm} / 1000 \mathrm{yrs}$ ); and, the form of the sediment body (Figures 15 and 16) with the wavy surface and characteristic marginal channels clearly indicates the influence of bottom currents. The simplest interpretation of these observations is to suggest that Norwegian Sea water, cascading over the Faroes-Iceland Ridge, not only sinks into the basins either side of Rockall Plateau but also spills along the top of the plateau between Hatton and Rockall Banks (see discussion in Chapter 8, this report). 


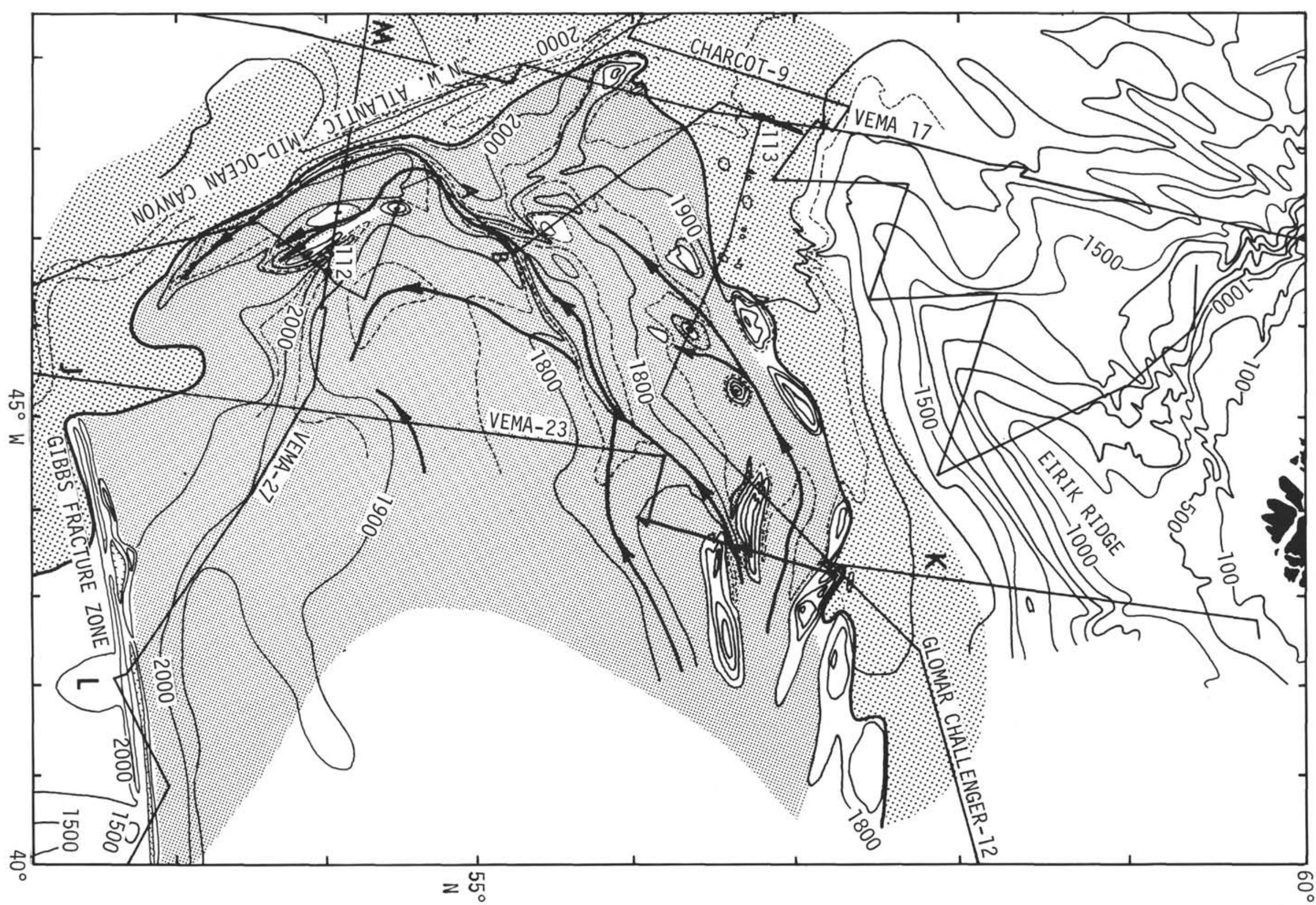

Figure 12. Bottom current sediment body (fine stipple) and turbidite sediments (coarse stipple) in the Southern Labrador Sea. Heavy lines indicate areas of sediment ridges. Depths in fathoms (uncorrected). 


\section{GRAIN SIZE FOR SITE 112}

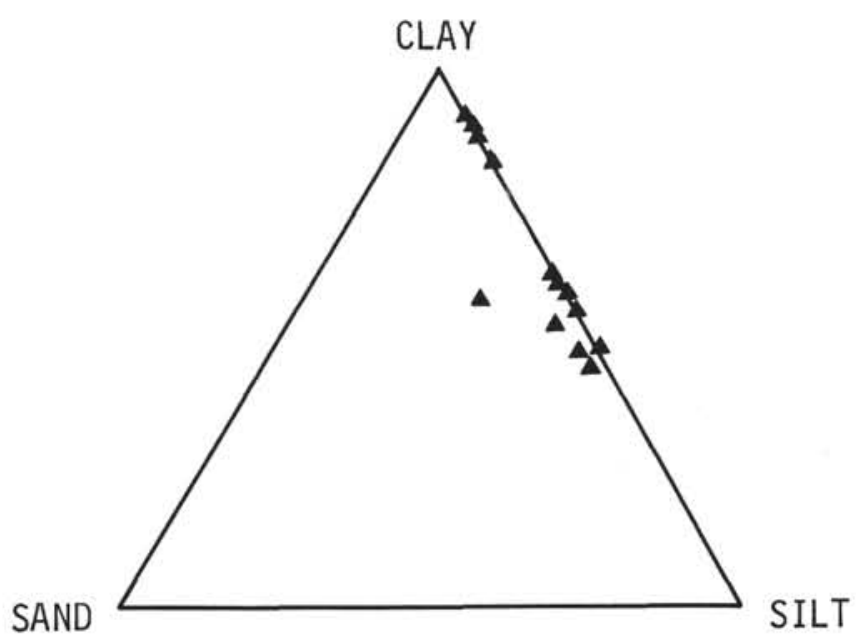

GRAIN SIZE FOR SITE 114

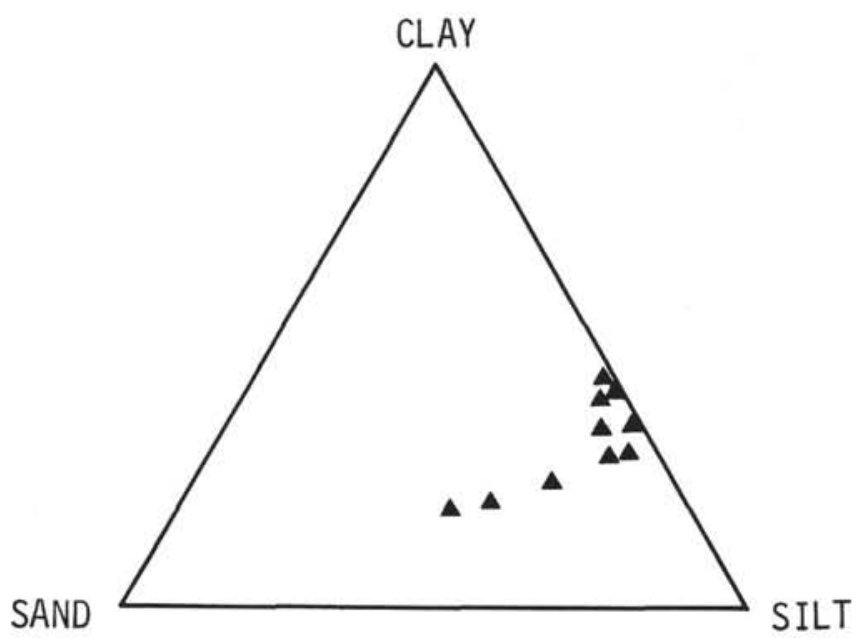

Figure 13. Triangle diagrams of sediment texture at Sites 112 and 114.

On the basis of the observations described above it is now possible to construct a slightly more comprehensive picture of the influence of bottom currents in the distribution of sediment in the North Atlantic Ocean. This has been done in Figure 17 where we have indicated the principal bottom current deposited sediment bodies and their crestal ridges.

\section{SURFACE CURRENTS}

The principal influence of surface currents is in the distribution of fine terrigenous material and biogenic material. An additional influence in high latitudes is in the distribution of ice-rafted continental debris. This will be discussed first, followed by a discussion of pelagic sedimentation.

\section{Ice-Rafting}

The influence of the Plio-Pleistocene glaciation was seen at all sites except Sites 115 and 117, where adequate samples were not obtained from the appropriate parts of the section (see also Chapter 13, this report). The most obvious change associated with the onset of glaciation is an increase in sedimentation rate at nearly all these sites. Table 1 shows that this occurs primarily in the noncarbonate (that is, nonbiogenous) component of the sediment.

Direct evidence of ice-rafting in the form of exotic pebbles and relatively poorly-sorted heterogeneous detrital sediments was seen at Sites 111, 112,113,114 and 119. On account of its proximity to Site 119 , it seems reasonable to suppose that Site 118 was also under the influence of ice-rafting, although clearly the dominant influence which produced a rise in sedimentation rate here was an increase in turbidity current activity associated with the lowered sea level during the glaciation. The same is probably also true for Site 113 .

Figure 18 shows the approximate locations of the sites at which ice-rafting is known to have been an influence, in relation to the present limits of drifting ice. Also indicated are the thicknesses of sediment which accumulated at each site during the glaciation. Clearly at Sites 113, 114 and 118 abnormally high sedimentation rates prevailed. As just mentioned, at Sites 113 and 118 this is due largely to increased turbidity current activity. At Site 114, as previously discussed, the apparent high sedimentation rate is probably due to the action of bottom currents piling up sediments from a large area in one place. The interesting fact which becomes clear from Figure 19 is that apparently ice-rafting was a major influence at Site 111, one of the more southerly sites drilled, and a comparatively minor influence at Site 116 on Rockall Bank, one of the more northerly sites. The present day distribution of drift ice and prevailing surface currents suggest that this is the result of a surface-current pattern not too far different from the present day system.

Evidence of ice-rafting has been reported from sediments cored at Lamont-Doherty Station R10-10 and irr the region of Peake Deep. At Station R10-10, Ericson et al. (1961) report "glacial marine layers" containing fragments of limestone and igneous rock up to 3 centimeters in diameter. In the Peake Deep region, Davies and Jones (1971) were able to trace variations in the composition and abundance of the detrital mineral component of the sediments which were attributed to ice-rafting during the cooler episodes of the glaciation. Glacial erratics resulting from ice-rafting have been dredged from the Peake Deep region (Cann and Funnell, 1967), from Galicia Bank (Black et al., 1964), Swallow Bank on the Iberian abyssal plain (Matthews, 1961 ) and from the mid-Atlantic Ridge at $45^{\circ} \mathrm{N}$ (Paterson, in press). Erratics from Galicia Bank contain a high proportion of recognizable European rocks (Matthews in Black et al., 1964), whereas those from the Peake Deep region contain no recognizable European types and probably originated in Greenland or Labrador (J. R. Cann, personal communication, in Davies, 1967). Pratt (1961) has 


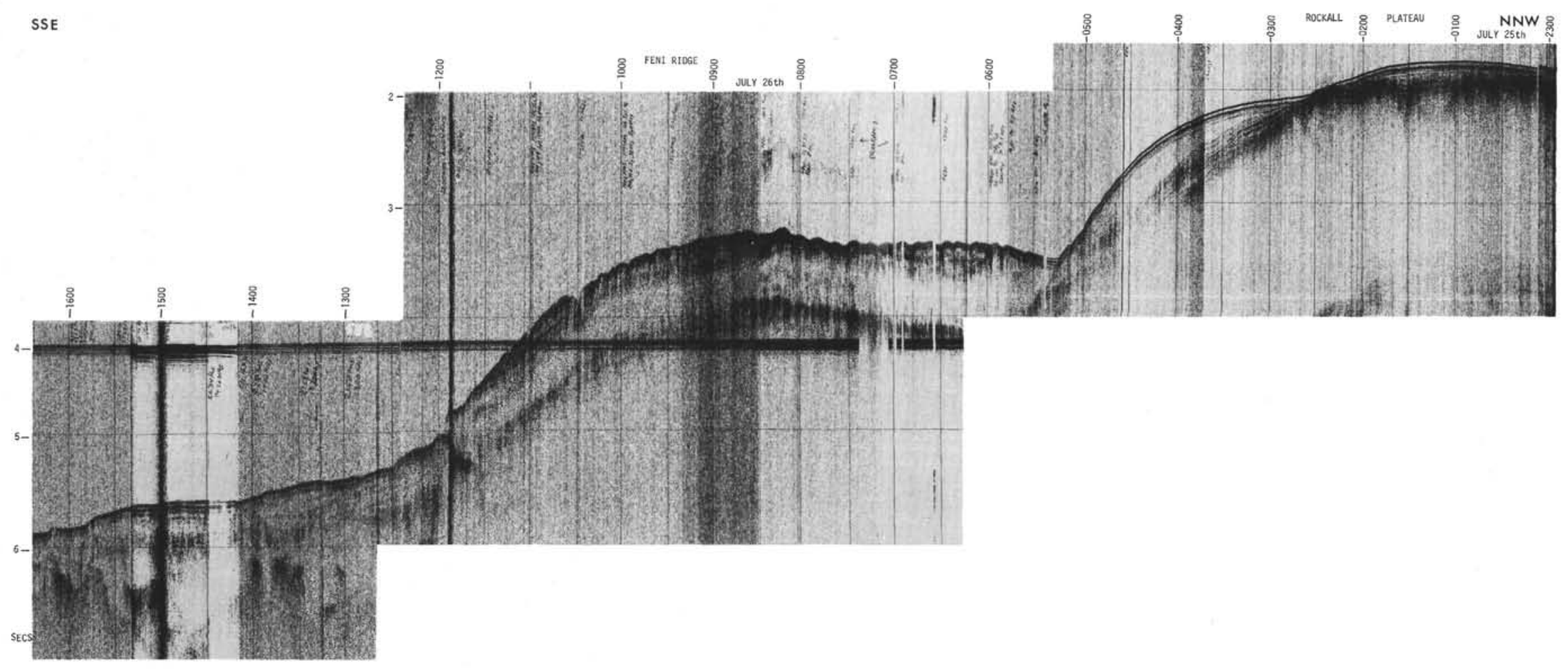

Figure 14. Seismic reflection profile from Rockall Plateau across Feni Ridge by Glomar Challenger-12. 


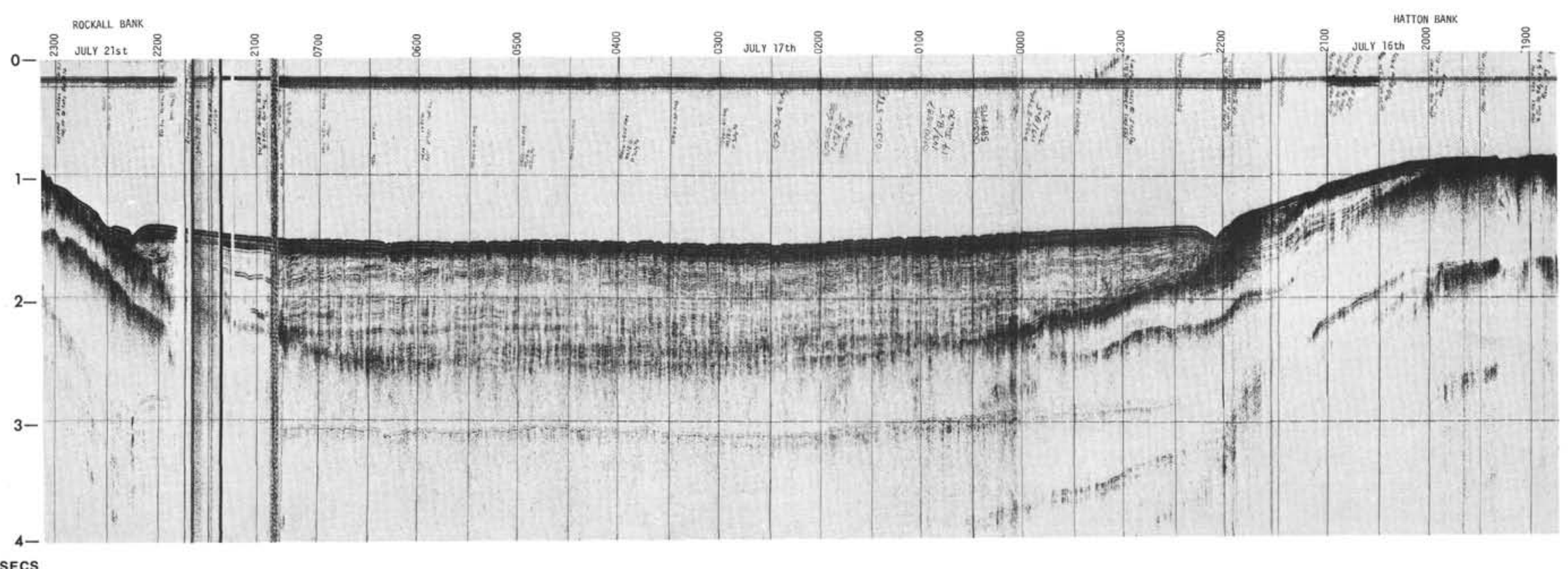

Figure 15. Seismic reflection profile across Hatton-Rockall Basin by Glomar Challenger-12. 


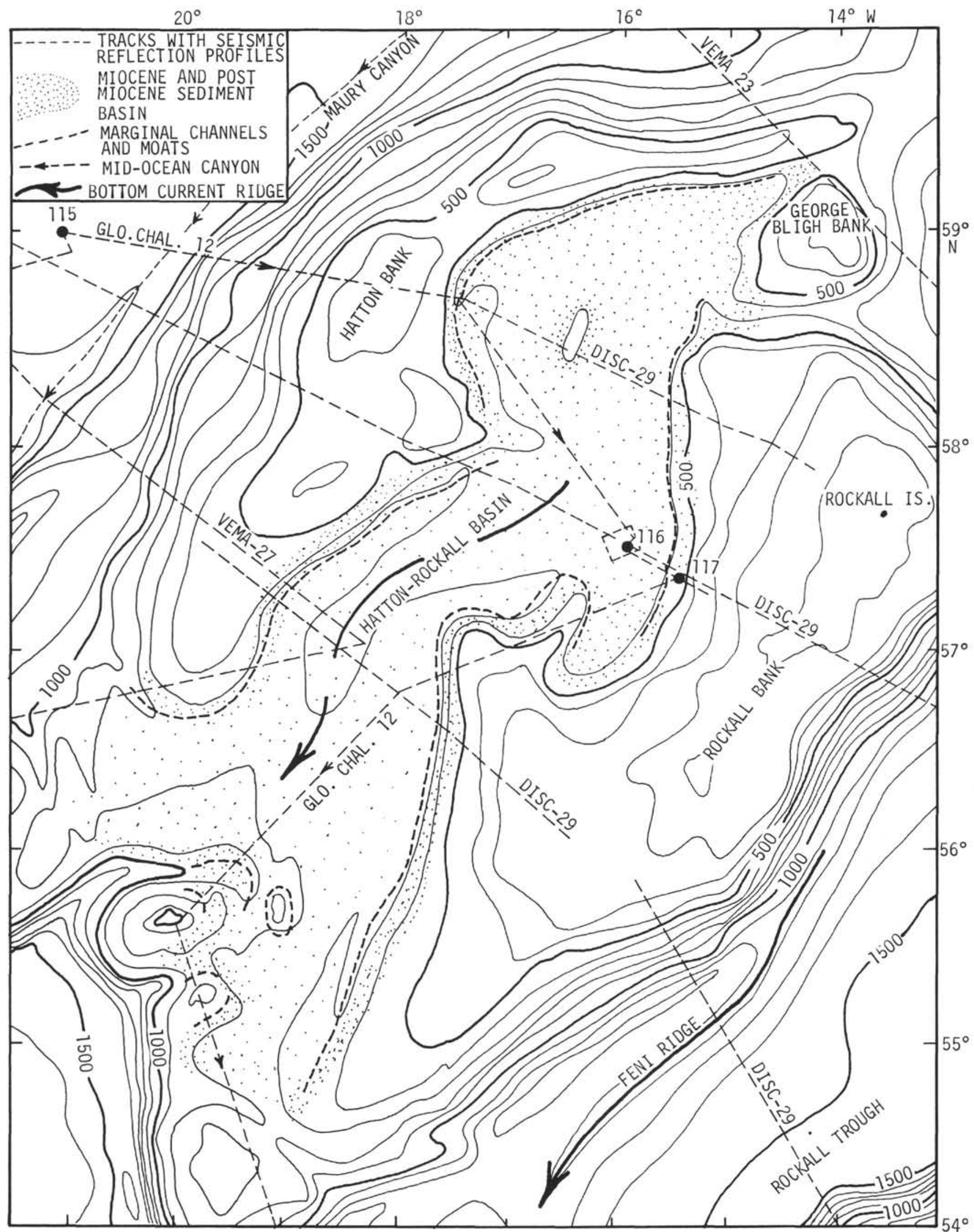

Figure 16. Bathymetric chart of Rockall Plateau showing extent of Miocene sediments in Hatton-Rockall Basin, the axis of sediment ridge, the marginal channels and moats. Depths in fathoms (corrected). 


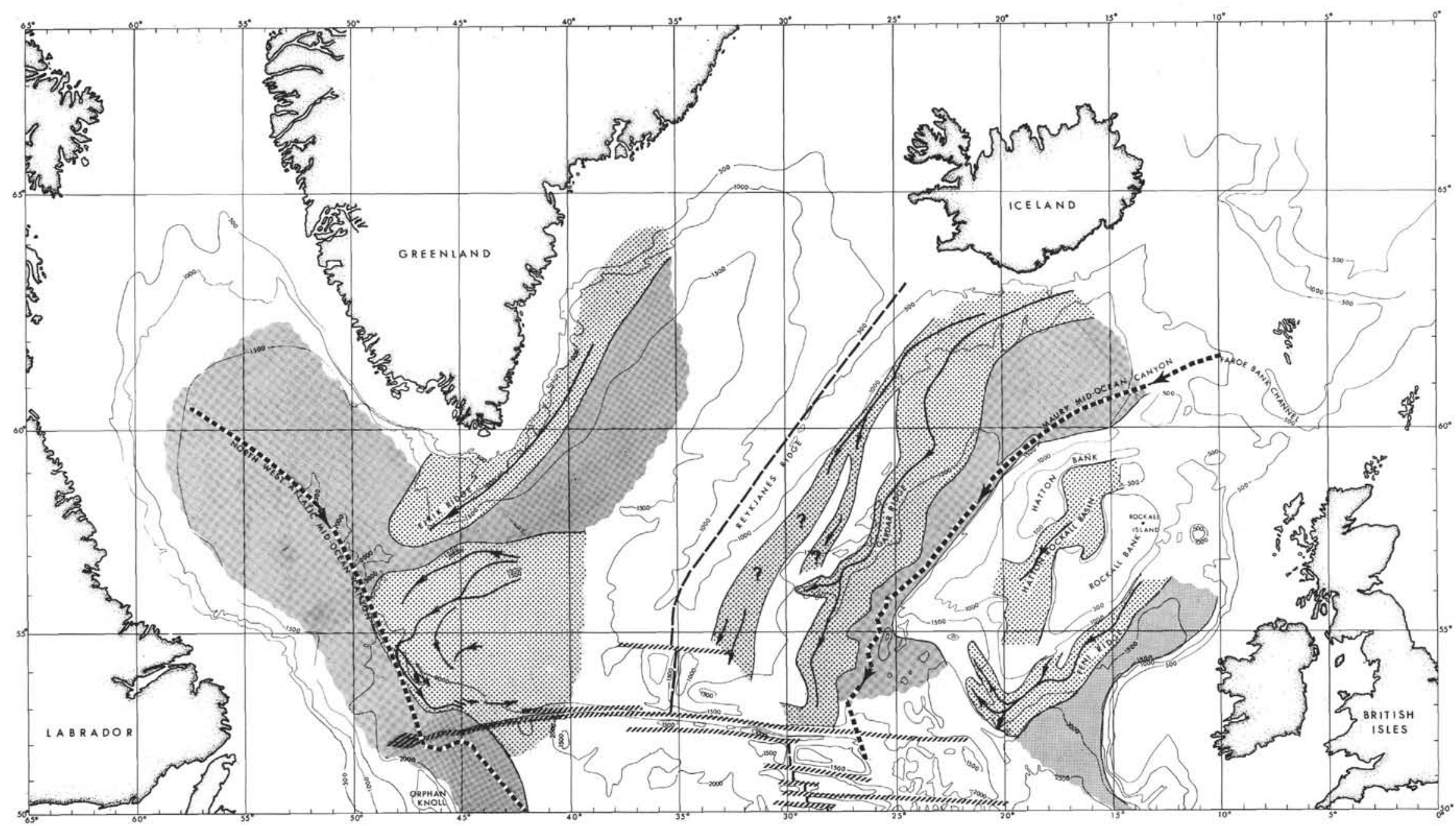

Figure 17. Bottom current sediment deposits (light stipple) and turbidite sediments (heavy stipple) in the North Atlantic.

Axes of sediment ridges (solid lines)

Axis of mid-ocean ridge (dashed line)

Fracture zones (diagonal lines)

Axes of mid-ocean canyons (dotted lines)

Depths in fathoms (uncorrected). 
TABLE 1

Thickness and Sedimentation Rates for the Glacial-Preglacial Section at Leg 12 Sites $^{\mathrm{a}}$

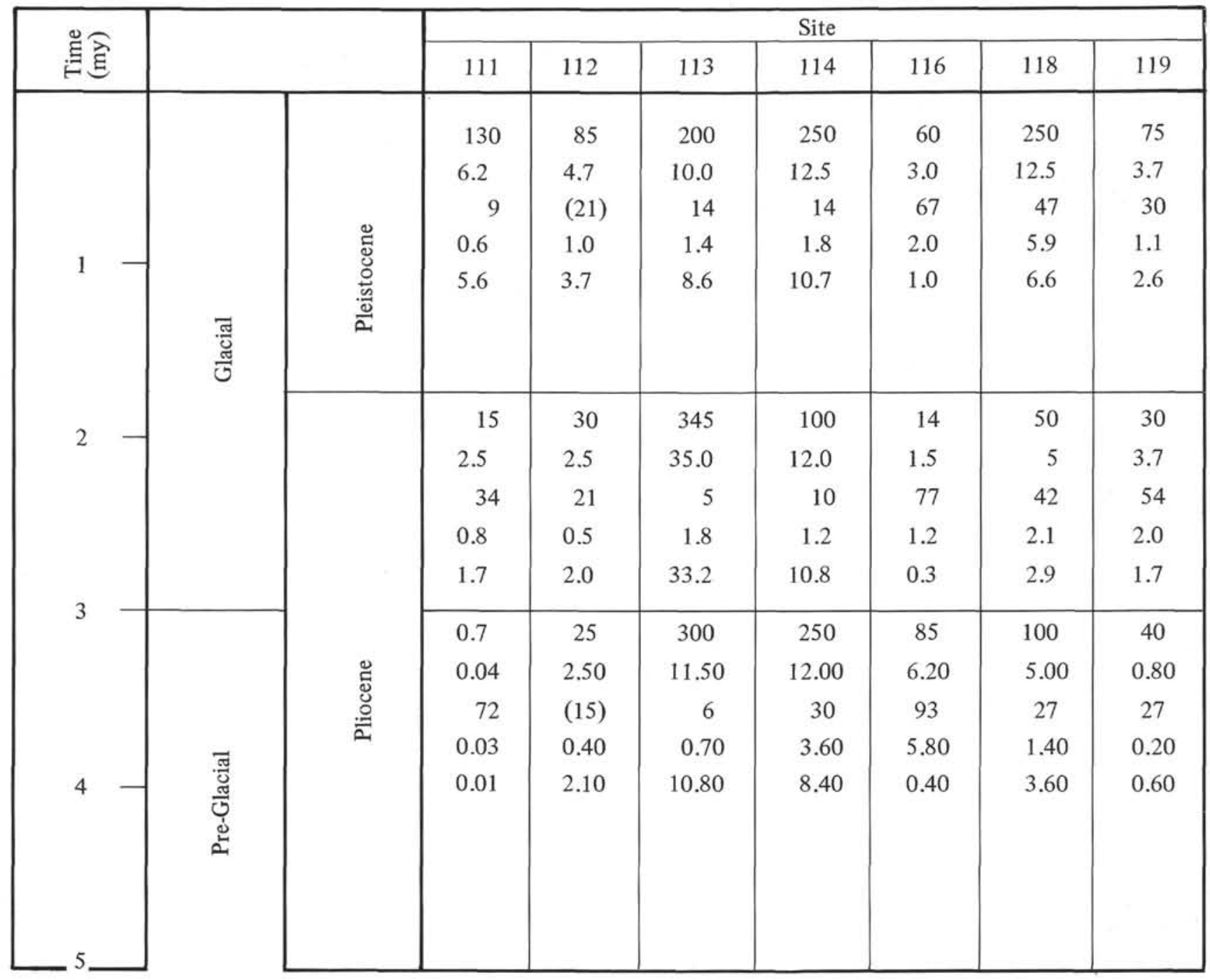

${ }^{a}$ Figures in each box are, from top to bottom; Thickness $(\mathrm{m})$, sedimentation rate $(\mathrm{cm} / 1000 \mathrm{yr})$, per cent $\mathrm{CaCO}_{3}$, sedimentation rate for $\mathrm{CaCO}_{3}(\mathrm{~cm} / 1000 \mathrm{yr})$, sedimentation rate for noncarbonate $(\mathrm{cm} / 1000 \mathrm{yr})$.

reported glacial erratics from Great Meteor Seamount. The southerly limit of glacial erratics in the eastern part of the North Atlantic is generally taken as $30^{\circ} \mathrm{N}$ (Matthews in Black et al., 1964). On the other hand, Peterson et al. (1970) make no mention of evidence of ice-rafting in their report of sediments sampled at DSDP Site 9 in the western North Atlantic, although this site sampled a section of Pleistocene foraminiferal oozes more than 80 meters in thickness. This is not surprising in view of the fact that the predominant surface currents in the western North Atlantic south of Newfoundland are now from the south, and probably were from this same direction even at times of maximum glaciation.

On the basis of these pieces of evidence, it is possible to construct a map showing the ice situation in the North Atlantic region at the time of maximum glaciation (Figure 19). The limits of the icecaps and coastline have been put at approximately the present day 100 -meter contour. The pack-ice/drift-ice boundary is largely speculative and is drawn on the assumption that the surface current system in the North Atlantic at the time of glacial advance was substantially the same as the present system but depressed to the south. Undoubtedly a more thorough search of the literature for records of evidence of ice-rafting would permit considerable refinement of Figure 19.

\section{Pelagic Sedimentation}

Pelagic sediments have been defined (Sverdrup, Johnson and Fleming, 1942) as those found in deep water far from shore, in contrast to terrigenous sediments adjacent to land. We have seen that ocean currents in the northern North Atlantic play a large part in transporting all types of sediment and in moulding the sediment deposits. In the absence of such currents or in very gentle current conditions, sediments from the water mass will settle on the bottom and blanket the bottom topography. They will be 


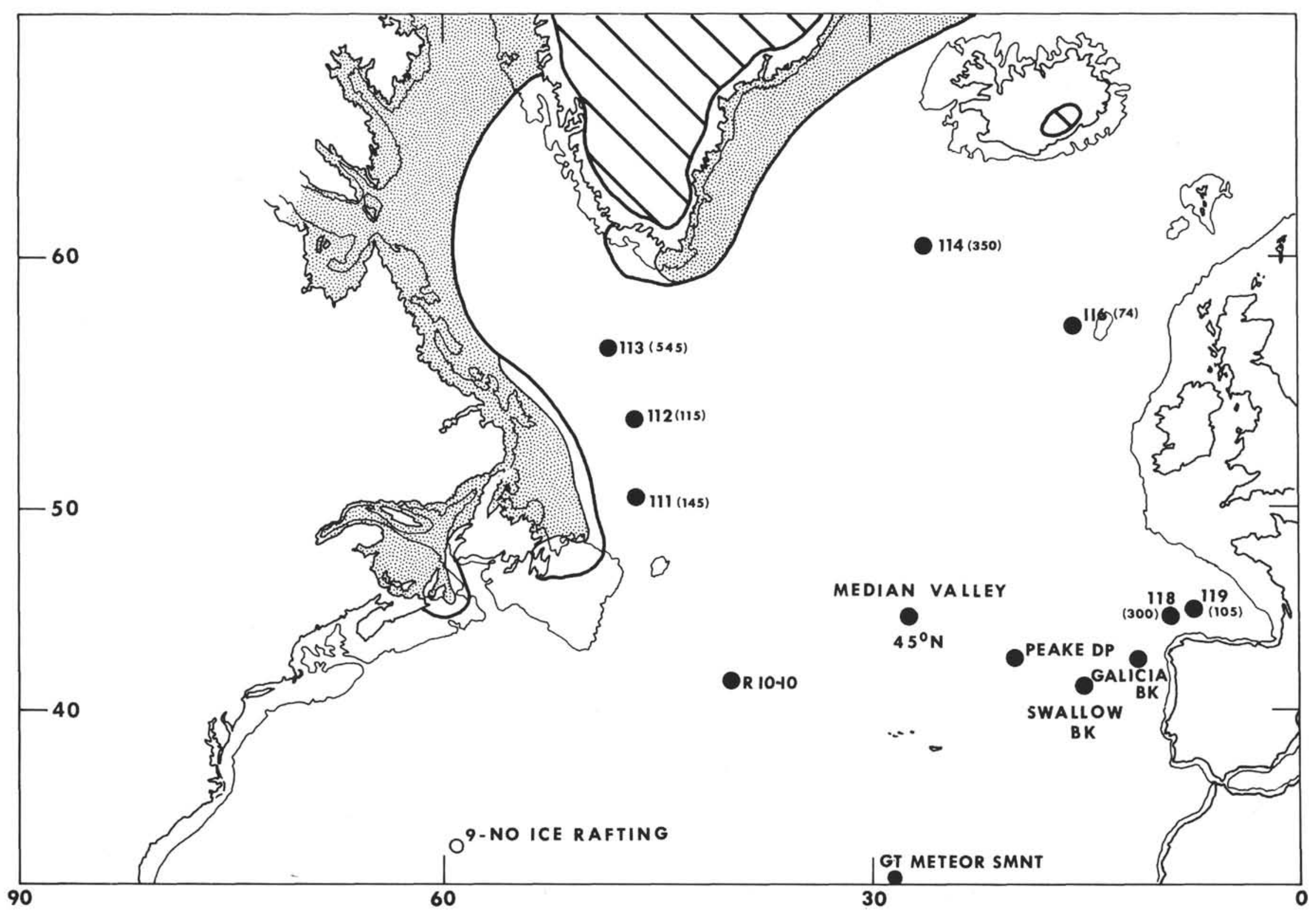

Figure 18. Sites where evidence of ice-rafting has been found (solid dots) with thickness of glacial section (in meters) and present day ice limits. 


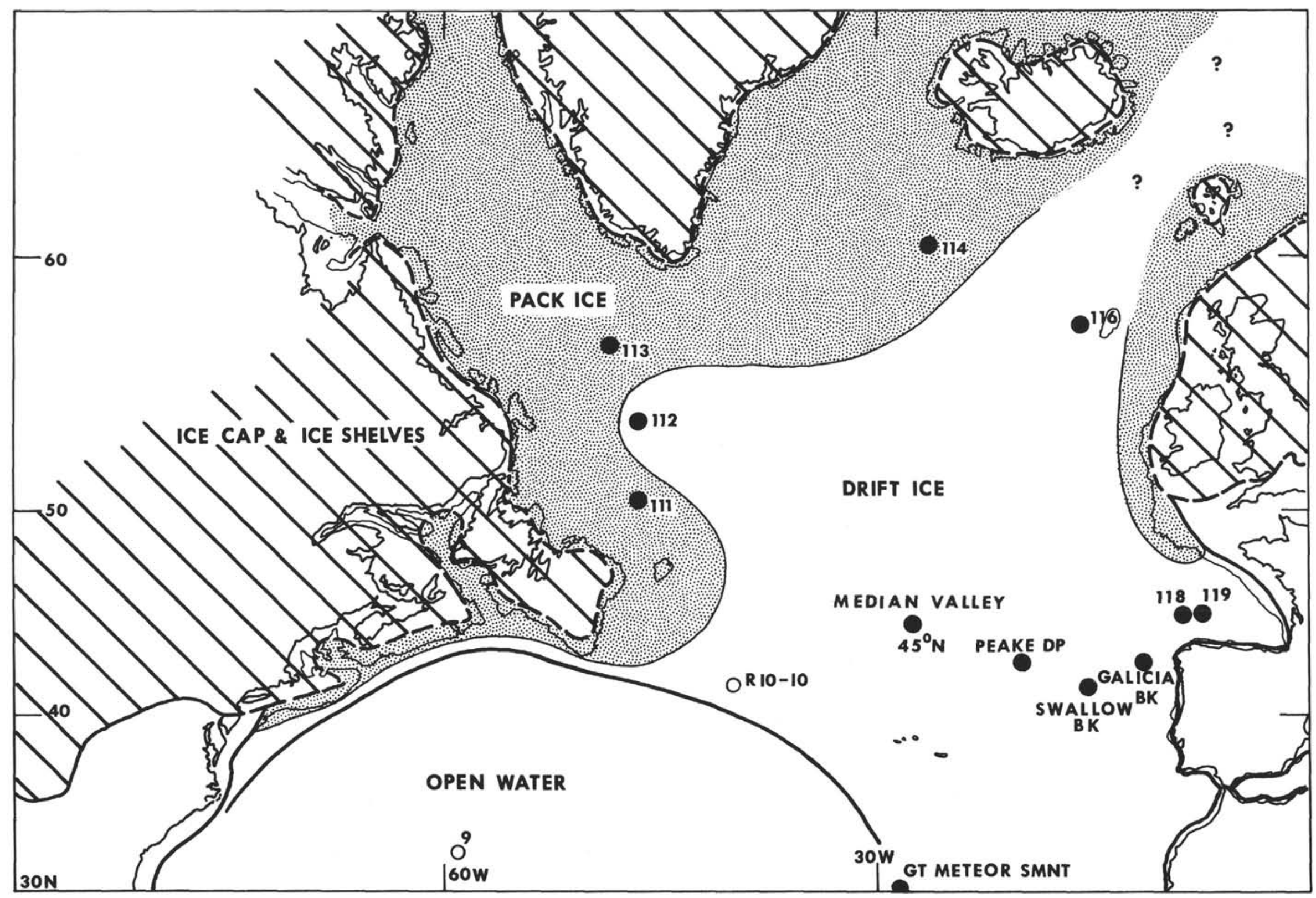

Figure 19. Suggested ice limits at maximum extent of glaciation. 
primarily biogenic with some clay. In this chapter, the term "pelagic sediments" is used to denote sediments laid down in deep water under quiet current conditions in contrast to bottom current sediments. They can be recognized partly by the nature of the sediment and partly by the aspect of the beds as seen on a seismic profile. It should be noted that this usage refers to a process rather than to sediment composition. Thus sediments of the Hatton-Rockall Basin (foraminiferal-nannofossil oozes) are essentially pelagic in composition but have clearly been laid down under the dominant influence of southward flowing bottom currents, hence in this report they are grouped with bottom current sediments.

Pelagic sediments, in this sense, are probably comparatively rare in the northern part of the North Atlantic. On Leg 12 they were sampled on Orphan Knoll (Site 111), in the Bay of Biscay (Sites 118, 119) and perhaps at Sites 112, 113 and 115 .

On Orphan Knoll the pelagic part of the section extends from the Maestrichtian to the present, with marked gaps in the record (Figure 1). Lithologically the sediments range from foraminiferal oozes and soft chalks to nannoplankton marls and zeolitic clays. At Site 113 similar nannofossil-rich sediments are found intercalated between the turbidites. At Site 112 a baked, faintly-laminated red clay was found at the very base of the section, resting on the basement. This clay is probably pelagic and owes its red coloration to the presence of the basalt (Bostrom and Peterson, 1969).

In the Bay of Biscay, pelagic sediments are found not only at the base of the section (Upper Paleocene to Middle-Eocene), but also intercalated between the Oligocene to Recent turbidites at Site 118 and intercalated between the Paleocene turbidites and forming the lower Eocene to Recent parts of the section on Cantabria Seamount (Site 119) (Figure 1). The situation in this region can be generalized by saying that the Paleocene and Lower Eocene pelagic sediments in the Bay of Biscay consist of gray and brown-red clays, and those pelagic sediments which accumulated after the Upper Eocene earth movements are the more usual gray nannofossil-rich clays and oozes.

It might be pointed out that the Paleocene and Lower Eocene sediments everywhere in the North Atlantic region appear to be zeolitic or red clays, very low in carbonate. This suggests broad regional variations in the depth of the lysocline through time (Benson, Gerard and Hay, 1970), which in turn reflects variations in the deep circulation within the Atlantic (Berggren and Hollister, 1971).

\section{SHALLOW WATER SEDIMENTS}

The shallow water sediments encountered on Orphan Knoll and Rockall Bank (Sites 111 and 117) demonstrate conclusively that these banks are in fact submerged continental fragments (cf. Chapters 3 and 8 , this volume).

On Orphan Knoll, thirty meters of Cretaceous shelly calcarenites are found overlying a Jurassic, non-marine sandstone. These calcarenites are relatively rich in quartz and coarse skeletal fragments in the lower part, with the quartz becoming rarer, and planktonic foraminifera and ostracods becoming more abundant upwards, suggesting a steadily increasing water depth and greater degree of isolation from terrigenous influences with the passage of time. The calcarenites are topped by a phosphatic pavement suggesting a hiatus in sedimentation while the water depth was still quite shallow. Overlying the calcarenite are soft chalks which probably accumulated in an outer shelf environment, that is, a 200-meter water depth, before the knoll sank to oceanic depths in Paleocene times.

On Rockall Bank a similar sedimentary history is seen. Here a Paleocene, sandy conglomerate is seen overlying a continental-type basalt. The conglomerate is composed predominantly of poorly reworked volcanic material resulting from erosion of a basalt similar to the basement. Although the conglomerate is poorly sorted, the constituent grains are altered and rounded. The overlying sandstone is better sorted than the material below, and contains mollusc shells, annelid tubes (Ditrupa sp) and is highly burrowed; the burrows having been infilled by carbonaterich material. This is overlain by sandy silt and silty clay which grades into a mudstone and clay. These sediments are all dark in color, contain mollusc shells (in particular, one specimen of an articulated Ostrea sp), bryozoa, larger foraminifera, and poorly reworked basalt fragments. The clay, like the sandstone, is also highly burrowed and contains a 3 centimeter-diameter phosphorite nodule, implying fairly shallow water. It is Lower Eocene in age.

After deposition of the clay, a considerable thickness of carbonates-now represented by cherty limestones-accumulated as Rockall Bank sank to its present depth in the early Tertiary.

At both Orphan Knoll and Rockall Bank we see that the basement is overlain by a near-shore, detrital-rich, sediment; there is evidence of gradual sinking for an extended period of time to a water depth of perhaps 200 meters accompanied by a decreasing terrigenous influence, with the sediments becoming more carbonate-rich. Finally these small continental fragments sank from shallow, outer shelf depths to their present depths and to a completely different type of sediment accumulation.

\section{DISCUSSION}

\section{Interaction of Sedimentary Processes in the Iceland Basin}

The basin south of Iceland provides an excellent example of the combined effects of the sedimentary processes just described.

Four quite distinct mechanisms of sedimentation have been active in the basin and have been responsible for the shape of the topography (Figures 10 and 20).

\section{(a) Bottom Currents}

The Gardar Ridge is the largest of several sediment ridges running parallel to the Reykjanes Ridge, which have been shaped by the southwesterly traveling Norwegian Sea overflow water, and which are found on the west side of the Iceland Basin. These ridges account for sedimentation over about half of the Basin (Figure 17).

Seismic profiles of the continental slope south of Iceland by Vema-27 show a considerable thickness of layered sediment which may also have been deposited by bottom currents. These sediments are draped over the topography associated with the two large canyons implying that the 


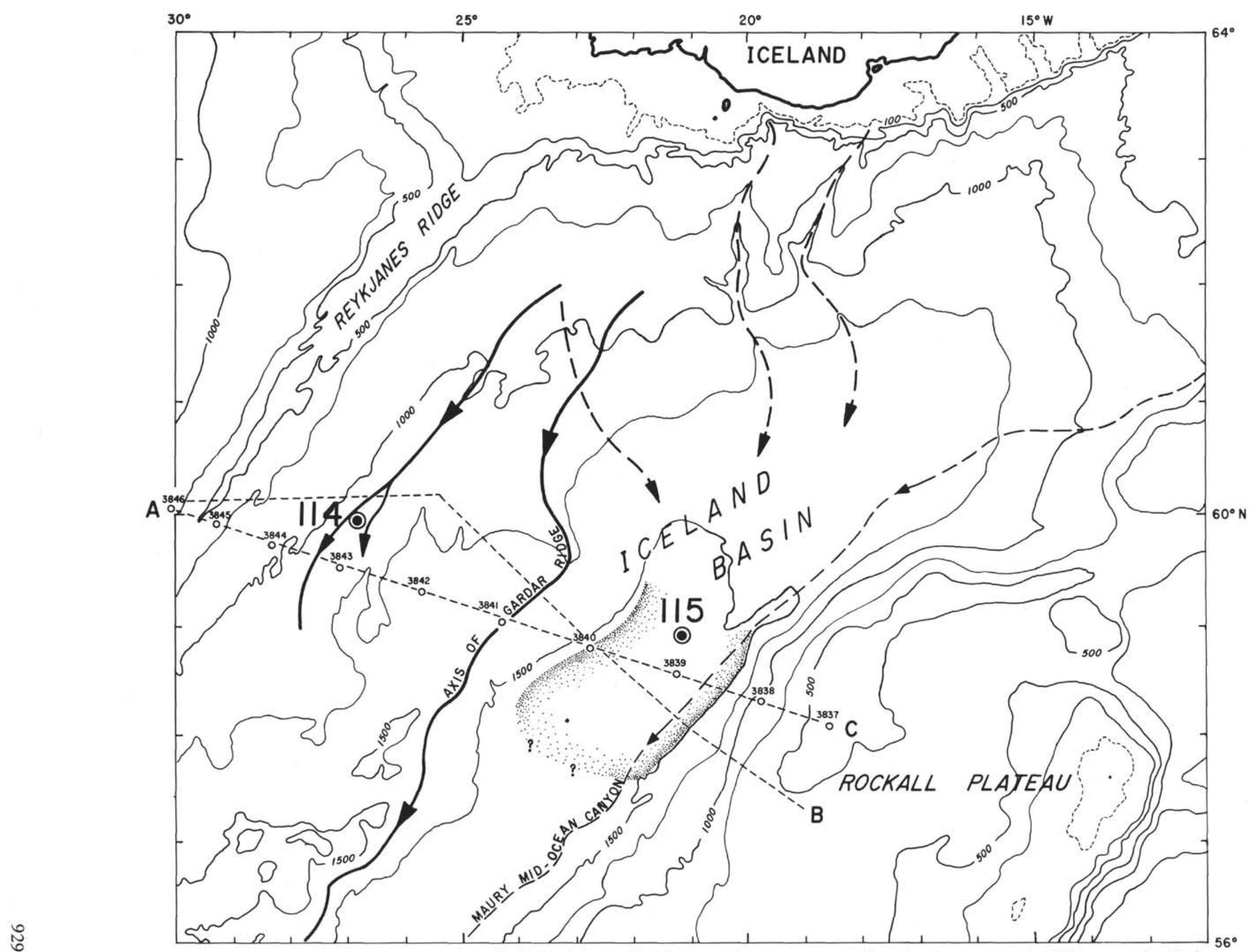


canyons were cut prior to the deposition of these sediments. However, they still appear to be used as paths by turbidity currents which have eroded a little of the draped sediments.

The sediments sampled in Hole 114 were predominantly clays and silts with relatively little carbonate (between 5 and 50 per cent). The bulk was terrigenous material containing abundant volcanic products. Much of this may have been derived from the finer fraction of volcanic material deposited on the continental slope south of Iceland or from the residual tails of turbidity currents, and subsequently retransported by the southwest flowing Norwegian Sea water.

\section{(b) Turbidity Currents}

Turbidity currents, generated from Icelandic jokulhlaups or from metastable accumulations of sediment on the shelf edge will travel downslope since they are gravity controlled and the effect of Coriolis' forces will tend to swing the paths to the right. Gravity however, will be the dominant control and hence a path may well cross over a bottom current path and sweep clean any sediments deposited there. The ultimate destination will be the lowest topographic depression, where the currents will die and the sediments be deposited in graded beds, as sampled at Site 115.

The turbidity currents will be spasmodic, the turbidite beds being interbedded with pelagic and other sediments. At Site 115 these were not recovered due to their softness in comparison to the indurated turbidites.

\section{(c) Low Velocity Density Currents}

The Maury Mid-Ocean Canyon (Johnson, Vogt and Schneider, 1971; Ballard, Bowles and Ruddiman, 1971) is in many respects similar to the Northwest Atlantic Mid-Ocean Canyon in the Labrador Sea (Heezen, Johnson and Hollister, 1969). It is over 1000 kilometers long stretching from the Faroe Bank Channel to a point southwest of Rockall Plateau. Under the name of Viking Seachannel, it has recently been traced as far as the Iberian Basin (Cherkis, Fleming and Fedin, 1971). In most places it is not more than 10 kilometers wide and 200 meters deep. It lies along the axis of greatest depth in the basin, and it has a steadily increasing depth to the southwest. Unlike the Northwest Atlantic Mid-Ocean Canyon, the Maury Canyon does not have prominent levees although there is a slight indication of one on the west side between $58^{\circ}$ and $59^{\circ} \mathrm{N}$.

Possible mechanisms for the production of Mid-Ocean Canyons were discussed by Heezen et al. (1969), but they could not establish a satisfactory one. There can be no doubt that a flow of bottom water is involved-controlled by a density difference-of a limited volume and low velocity in order to be retained within the channel. The connection with the Faroe Bank Channel at the northeast end suggests that the water originates in the Norwegian Sea. The flow may, however, be sporadic. The velocity must be enough either to prevent or retard sedimentation along the axis or to erode pre-existing sediments. Since it lies above the indurated volcanogenic sandstones of Site 115, the present day topographic feature must be a late Quaternary one. Whether the density contrast arises from physical and chemical characteristics or from suspended sediment or both remains an unsolved question.

\section{(d) Pelagic Sediments}

When no other influences are at work and the currents are small, pelagic sediments can accumulate. These will be partly biogenic and partly from fine suspended terrigenous clays. Authigenic minerals may also contribute. The pelagic contribution cannot easily be distinguished from the bottom current deposits, but will be interbedded with the turbidites.

The net result of these four sedimentary processes acting in the Iceland Basin, varying with time and in space, is a very complex accumulation of sediments in three dimensions. Although one area may be labeled "bottom current sediments" or "turbidites", the beds interfinger and are often hard to distinguish.

\section{Sedimentation and Tectonics}

In the foregoing account of the distribution of sediment in the northern North Atlantic we have largely ignored the dimension of time. However, the overall distribution of sediments is a result of various processes operating throughout both space and time. Since the processes of sediment dispersion are largely the direct or indirect result of oceanographic conditions which, in turn, are profoundly influenced by the shape and orientation of the ocean basin, it follows that a full understanding of the distribution of sediments will not emerge until we take an account of the tectonic history of the region and changing geometry of the North Atlantic Ocean through time.

Leg 12 provided two small-scale examples of the relationship between sedimentation and tectonics which are worthy of note. Perhaps the simplest is from the Bay of Biscay, where drilling at Sites 118 and 119 produced samples of thick coarse turbidites of shallow water carbonate debris laid down at these sites immediately after Eocene earth movements in the Aquitaine, many miles away and up-slope from the depositional sites, had disturbed and uplifted such sediments, exposing them to erosion. The relationships are summarized in Figure 21, where events at the different localities are shown against a common time scale. At Sites 118 and 119, the Eocene uplift profoundly changed the nature of the sediments subsequently deposited.

A more complex example is provided by the sedimentary histories of Orphan Knoll and Rockall Plateau. Prior to their sinking, these continental fragments apparently had similar sedimentation histories. After sinking, the sedimentation on Orphan Knoll has been predominantly pelagic, whereas that on Rockall Plateau has been under the control of bottom currents. This is to be expected from the geographic location of the two sites.

On the larger scale, the accumulation of bottom current sediments at Site 112 spans the whole Tertiary during which time the size and shape of the northern North Atlantic changed considerably. The mid-sediment reflector seen in the southern Labrador Sea, and dated in Hole 112 as Oligocene, has its counterpart on the eastern side of the mid-Atlantic Ridge at the southern end of the Gardar Ridge. If the North Atlantic is closed back to its Oligocene 


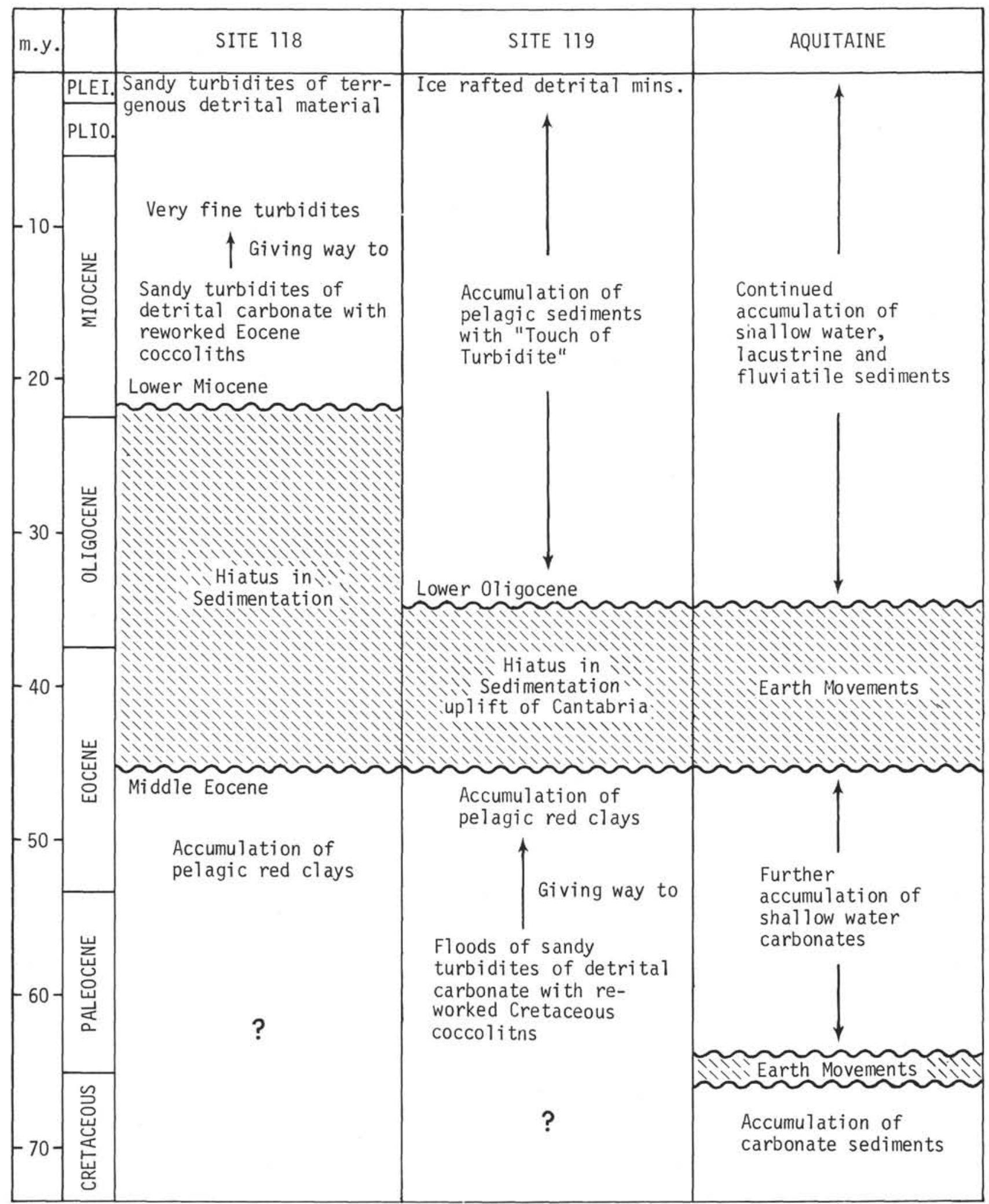

Figure 21. Relationship between sedimentation at Sites 118 and 119, and tectonic events in the Aquitaine (based on data from Bonnard et al., 1958). 
size, the south end of the Gardar Ridge is relatively close to the sediment body in the South Labrador Sea and may even have been joined to it (Figure 22). It is possible that prior to the mid-Oligocene, the Reykjanes Ridge was a much less pronounced feature than it is now (Iceland is believed to be not more than 20 million years old) and that the early Gardar Ridge may have extended over into the western side. At this time, there were many east-west fracture zones crossing the ridge (Vogt et al., 1969) providing easy access routes.

Although there are well-known analyses of the distribution of sediments as a consequence of the tectonic history of a region for the older parts of the geologic record (see Pettijohn, 1957; Krumbein and Sloss, 1963; and, Gilluly, Waters and Woodford, 1968, for examples) there have not been many examples involving fairly recent marine environments, with the exception of certain restricted regions, for example the Northwest Gulf of Mexico (Shepard, Phleger and van Andel, 1960) and the Gulf of California (van Andel and Shor, 1964) and certain coastal regions. With the advent of deep sea drilling, however, allowing the recovery of long sedimentary sections from the deep parts of the ocean basins, it should become increasingly possible to build an integrated picture of the development of the ocean basins and their sedimentary infill. The theme of the relationship between sedimentation and tectonics in the North Atlantic has been developed by Berggren and Hollister (1971) and Laughton (Chapter 20, this volume), and the subsidiary topic of the relationship between sedimentary facies and sea-floor spreading has been explored by Maxwell et al. (1970, a and b) so these topics will not be further discussed here.

\section{REFERENCES}

Ballard, J. A., Bowles, F. A. and Ruddiman, W. F., 1971. Maury Channel and Fan (Abs.). Trans. Am. Geophys. Union. 52, 243.

Benson, W. E., Gerard, R. D. and Hay, W. W., 1970. Summary and conclusions. In Bader, R. G. et al., 1970. Initial Reports of the Deep Sea Drilling Project, Volume $I V$. Washington (U.S. Government Printing Office) 659.

Berggren, W. A. and Hollister, C., 1971. Biostratigraphy and History of Circulation of North Atlantic (abstract). Bull. Am. Assoc. Petrol. Geol. 55, 331.

Black, M., Hill, M. N., Laughton, A. S. and Matthews, D. H., 1964. Three non-magnetic seamounts off the Iberian Coast. Quart. J. Geol. Soc. London. 120, 477.

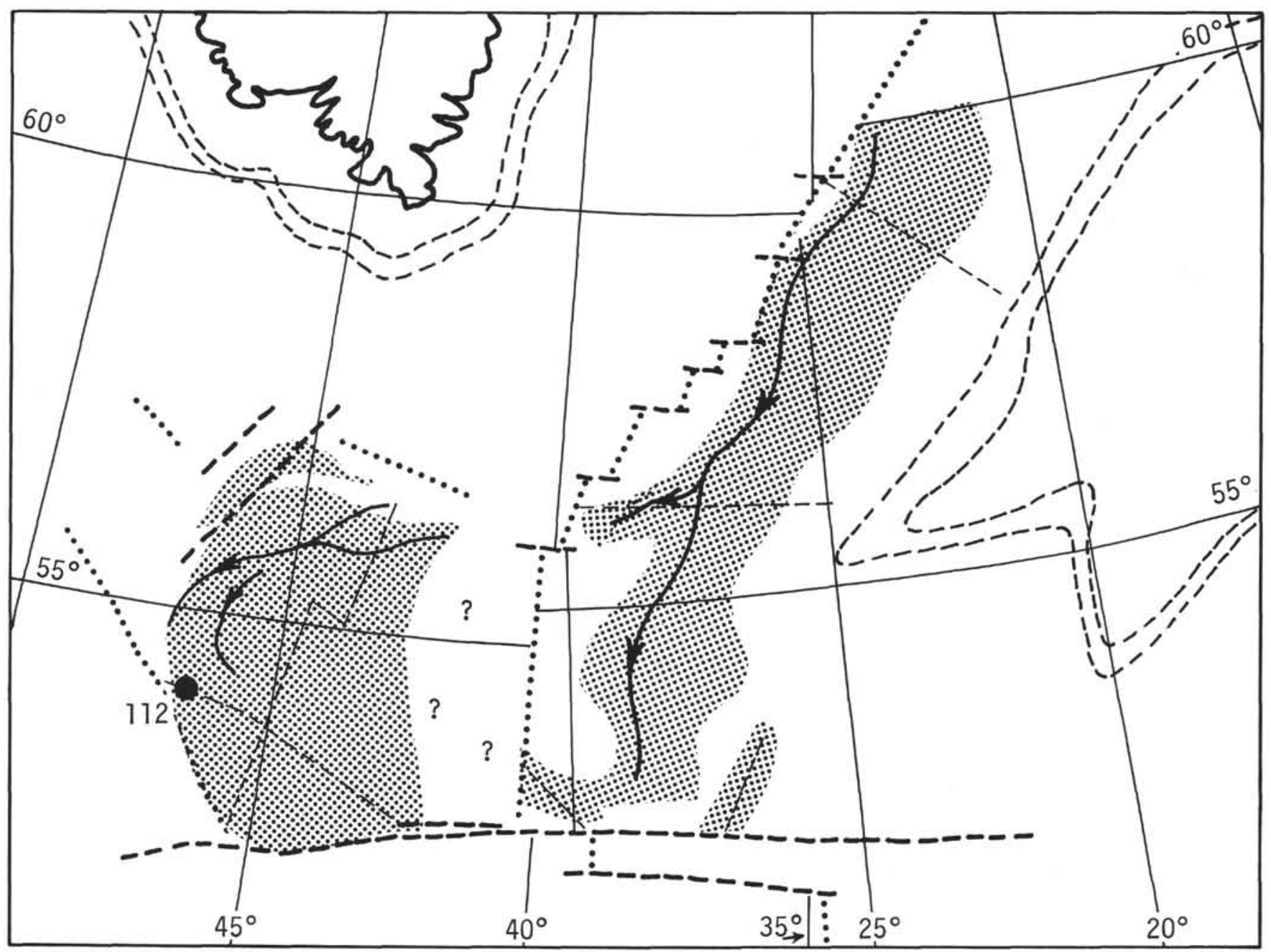

Figure 22. The North Atlantic in Mid-Oligocene (35 million years) showing Gardar Ridge adjacent to sediment body in South Labrador Sea. 
Boström, K. and Peterson, M. N. A., 1969. The origin of aluminum-poor ferromanganoan sediments in areas of high heat flow on the East Pacific Rise. Marine Geol. 7, 427.

Bonnard, E., Debourle, A., Hlauschek, H., Michel, P., Perebaskine, V., Schoeffler, J., Seronie-Vivien, R. and Vigneaux, M., 1958. The Aquitanian Basin, Southwest France. In Habitat of Oil. Weeks, L. G. (Ed.), Tulsa (Am. Assoc. Petrol. Geol.) 1091.

Bramlette, M. N. and Bradley, W. H., 1940. Geology and biology of North Atlantic deep-sea cores between Newfoundland and Ireland. Part 1: Lithology and geologic implications. U.S. Geol. Surv. Profess. Paper 196-A.

Bryan, G. M., 1970. Hydrodynamic model of the Blake Outer Ridge. J. Geophys. Res. 75, 4530.

Cann, J. R. and Funnell, B. M., 1967. Palmer Ridge: A section through the upper part of the ocean crust? Nature. 213, 661.

Cherkis, N. Z., Fleming, H. S. and Fedin, R. H., 1971. The Viking Seachannel in the eastern North Atlantic (Abs.). Trans. Am. Geophys. Union. 52, 243.

Davies, T. A., 1967. Recent sedimentation in the Northeast Atlantic: the Iberian Abyssal Plain and the region south of Peake Deep. PhD Thesis, Cambridge University

Davies, T. A. and Jones, E. J. W. (1971). Sedimentation in the region of Peake and Freen Deeps (mid-Atlantic Ridge). Deep Sea Res. 18, 619.

Ericson, D. B., Ewing, M., Wollin, G. and Heezen, B. C., 1961. Atlantic deep-sea sediment cores. Bull. Geol. Soc. Am. 72, 193.

Ewing, M. et al., 1969. Initial Reports of the Deep Sea Drilling Project, Volume I. Washington (U.S. Government Printing Office) 672 pp.

Fischer, A. G. and Beall, A. O., 1969. Sedimentology. In Ewing, M. et al., 1969. Initial Reports of the Deep Sea Drilling Project, Volume I. Washington (U.S. Government Printing Office) 521.

Fox, P. J. and Heezen, B. C., 1968. Abyssal antidunes. Natures. 220, 470.

Fuglister, F. C., 1960. Atlantic Ocean Atlas. Massachusetts (Woods Hole Oceanographic Institution) $209 \mathrm{pp}$.

Garner, D. M. (in press). Flow through the Charlie-Gibbs Fracture Zone, mid-Atlantic Ridge. Can. J. Earth Sci,

Gilluly, J., Waters, A. C. and Woodford, A. O., 1968. Principles of Geology. (3rd edition) San Francisco (Freeman) $686 \mathrm{pp}$.

Heezen, B. C., 1959. Dynamic processes of abyssal sedimentation. Geophys. J. 2, 142.

1963. Turbidity currents. In The Sea. Hill, M. N. (Ed), III. New York (Interscience) 742.

B. C. and Hollister, C. D., 1964. Deep-sea current evidence from abyssal sediments. Marine Geol, 1, 141.

, B. C. and Johnson, G. L., 1963. A moated knoll in the Canary passage. Deutschen. Hyd. Zeit. 16, 269.

B. C. and Laughton, A. S., 1963. Abyssal plains. In The Sea. Hill, M. N. (Ed), III. New York (Interscience) 312

B. C. Hollister, C. D. and Ruddiman, W. F., 1966. Shaping of the continental rise by deep geostrophic contour currents. Science. 152, 502 .

B. C., Johnson, G. L. and Hollister, C., 1969. The Northwest Atlantic Mid-Ocean Canyon. Can. J. Earth Sci. 6, 1441.

Hollister, C. D. and Heezen, B. C., 1967. Contour current evidence from abyssal sediments. Trans. Am. Geophys. Union. 48, 142.
Johnson, G. L. and Schneider, E. D,, 1969. Depositional ridges in the North Atlantic. Earth. Planetary Sci. Letters. 6, 416.

G. L., Closuit, A. W. and Pew, J. A., 1969.

Geological and geophysical observations in the Northern Labrador Sea. Arctic. 22, 56.

, G. L., Vogt, P. R. and Schneider, E. D. (1971). Morphology of the Northeastern Atlantic and Labrador Sea. Deutschen Hyd. Zeit. 24, 49.

Jones, E. J. W., Ewing, M., Ewing, J. and Eittreim, S. L., 1970. Influences of Norwegian Sea overflow water on sedimentation in the northern North Atlantic and Labrador Sea. J. Geophys. Res. 75, 1655.

Krumbein, W. C. and Sloss, L. L., 1963. Stratigraphy and Sedimentation. San Francisco (Freeman) 660 pp.

Kuenen, P. H., 1937. Experiments in connection with Daly's hypothesis on the formation of submarine canyons. Leid. Geol. Meded. 8, 327.

1951. Properties of turbidity currents of high density. In Turbidity Currents-A symposium. Hough, J. L. (Ed.) Soc. Econ. Pal. \& Min. Spec. Publ. No. 2. 1964. Deep sea sands and ancient turbidites. In Turbidites. Bouma, A. H. and Brouwer, A. (Eds.), Amsterdam (Elsevier).

, 1966. Experimental turbidite lamination in a circular flume. J. Geol. 74, 523.

Le Pichon, X., Ettreim, S. and Ewing, J. I. 1971. A sedimentary channel along Gibbs Fracture Zone. J. Geophys. Res. 76, 2891.

Le Pichon, X., Hyndman, R. and Pautot, G. (1971). A geophysical study of the opening of the Labrador Sea. $J$. Geophys. Res. 76, 4724.

Mann, C. R., 1969. Temperature and salinity characteristics of the Denmark Strait overflow. Deep-Sea Res. Supp. to $16,125$.

Markl, R. G., Bryan, G. M. and Ewing, J. I., 1970. Structure of the Blake-Bahama Outer Ridge.J. Geophys. Res., 75, 4539 .

Matthews, D. H., 1961. Rocks from the eastern North Atlantic. $\mathrm{PhD}$ Thesis, Cambridge University.

Maxwell, A. E., et al., 1970(a). Initial Reports of the Deep Sea Drilling Project, Volume III. Washington (U.S. Government Printing Office) 806 pp.

Maxwell, A. E., Von Herzen, R. P., Hsu, K. J., Andrews, J. E., Saito, T., Percival, S. F., Milow, E. D. and Boyce, R. E., 1970(b). Deep sea drilling in the South Atlantic. Science. 168, 1047.

Murray, J. and Renard, A. E., 1891. Deep sea deposits. Reports of H.M.S. Challenger 1873-1876.

Paterson, I. S. (in press). The mid-Atlantic Ridge near $45^{\circ}$ N. XVI. Pleistocene glacial erratics. Can. J. Earth Sci.

Peterson, M. N. A. et al., 1970. Initial Reports of the Deep Sea Drilling Project, Volume II. Washington (U.S. Government Printing Office) $500 \mathrm{pp}$.

Pettijohn, F. J., 1957. Sedimentary Rocks. (2nd edition). New York (Harper) $718 \mathrm{pp}$.

Pimm, A. C., Garrison, R. E. and Boyce, R. E., 1971. Sedimentary synthesis: Lithology, chemistry and physical properties of sediments in the northwestern Pacific Ocean. In Fischer, A. G. et al., 1971. Initial Reports of the Deep Sea Drilling Project Volume VI. Washington (U.S. Government Printing Office) 1131.

Pratt, R. M., 1961. Erratic boulders from Great Meteor Seamount. Deep Sea Res. 8, 152.

Rona, P. A., 1971. Depth distribution in ocean basins and plate tectonics. Nature. 231, 179.

Shepard, F. P., 1948. Submarine Geology. Harper \& Bros. New York, 338 pp. 
Shepard, F. P., Phleger, F. B. and Van Andel, Tj. H., 1960. Recent Sediments, Northwest Gulf of Mexico. Tulsa (Am. Assoc. Petrol. Geol.) 394 pp.

Schneider, E. D., Fox, P. J., Hollister, C. D., Needham, H. D. and Heezen, B. C., 1967. Further evidence of contour currents in the western North Atlantic. Earth Planetary Sci, Letters. 2, 351.

Sverdrup, H. U., Johnson, M. W. and Fleming, R. H., 1942. The Oceans. New York (Prentice-Hall Inc.), 1087 pp.

Talwani, M., Windisch, C. C. and Langseth, M. G., 1971. Reykjanes Ridge Crest: A detailed geophysical survey. $J$. Geophys. Res. 76, 473.

Van Andel, Tj. H. and Shor, G. G., 1964. Marine geology of the Gulf of California. Am. Assoc. Petrol. Geol. Memoir. No. 3408 pp.

Vogt, P. R., Avery, O. E., Morgan, W. J., Johnson, G. L., Schneider, E. D. and Higgs, R. H., 1969. Morphology, magnetic anomalies and evolution of the Northeast Atlantic and Labrador Sea, Part III-Evolution. Trans. Am. Geophys. Union. 50, 184.

Weser, O. E., 1970. Lithologic summary. In McManus, D. A., et al., 1970. Initial Reports of the Deep Sea Drilling Project, Volume V. Washington (U.S. Government Printing Office) 569.

Worthington, L. V., 1969. An attempt to measure volume transport of Norwegian Sea overflow water through the Denmark Strait. Deep-Sea Res. Supp. to 16, 421 .

Worthington, L. V., 1970. The Norwegian Sea as a Mediterranean basin. Deep-Sea Res. 1777.

Worthington, L. V. and Volkmann, G. H., 1965. The volume transport of the Norwegian Sea overflow water in the North Atlantic. Deep Sea Res. 12, 667. 